\title{
Regulation and roles of the hyaluronan system in mammalian reproduction
}

\author{
Ali A Fouladi-Nashta ${ }^{1}$, Kabir A Raheem ${ }^{1,2}$, Waleed F Marei ${ }^{1,3}$, Fataneh Ghafari ${ }^{1}$ and \\ Geraldine $M$ Hartshorne ${ }^{4}$ \\ ${ }^{1}$ Royal Veterinary College, Reproduction Research Group, Hawkshead Campus, Hatfield, UK, ${ }^{2}$ Department of \\ Veterinary Surgery and Theriogenology, Michael Okpara University of Agriculture, Umudike, Nigeria, \\ ${ }^{3}$ Department of Theriogenology, Faculty of Veterinary Medicine, Cairo University, Giza, Egypt and \\ ${ }^{4}$ Warwick Medical School, University of Warwick, Coventry, UK and Centre for Reproductive Medicine, \\ University Hospitals Coventry and Warwickshire NHS Trust, Coventry, UK
}

Correspondence should be addressed to A A Fouladi-Nashta; Email: afouladi@rvc.ac.uk

\begin{abstract}
Hyaluronan (HA) is a non-sulphated glycosaminoglycan polymer naturally occurring in many tissues and fluids of mammals, including the reproductive system. Its biosynthesis by HA synthase (HAS1-3) and catabolism by hyaluronidases (HYALs) are affected by ovarian steroid hormones. Depending upon its molecular size, HA functions both as a structural component of tissues in the form of high-molecular-weight HA or as a signalling molecule in the form of small HA molecules or HA fragments with effects mediated through interaction with its specific cell-membrane receptors. HA is produced by oocytes and embryos and in various segments of the reproductive system. This review provides information about the expression and function of members of the $\mathrm{HA}$ system, including HAS, HYALs and HA receptors. We examine their role in various processes from folliculogenesis through oocyte maturation, fertilisation and early embryo development, to pregnancy and cervical dilation, as well as its application in assisted reproduction technologies. Particular emphasis has been placed upon the role of the HA system in pre-implantation embryo development and embryo implantation, for which we propose a hypothetical sequential model.

Reproduction (2017) 153 R43-R58
\end{abstract}

\section{Introduction}

Hyaluronan (HA), also known as hyaluronic acid or hyaluronate, is a high-molecular-weight anionic member of a group of macromolecules called glycosaminoglycans (GAGs) that constitute the components of the extracellular matrix (ECM) in all animal tissues. Other GAGs include heparin sulphate, dermatan sulphate, keratan sulphate and chondroitin sulphate. HA is the simplest of all the GAGs and has a number of unique properties that distinguish it from other GAGs. (i) It is nonsulphated, (ii) it is a linear polysaccharide of thousands of repeated units of alternating D-glucuronic acid and $\mathrm{N}$-acetylglucosamine (Weissmann et al. 1954), (iii) it is synthesised at the plasma membrane rather than in the Golgi apparatus (Prehm 1984), (iv) it is extruded into ECM via the cell surface as it is synthesised (Tammi et al. 2002) and (v) HA is not restricted to the ECM, rather, its intracellular localisation has also been reported (Contreras-Ruiz et al. 2011).

The concentrations of HA within the reproductive tract vary from one mammalian species to another. Some examples are provided in Table 1. HA is present in the oviduct, uterus and cervix (Afify et al. 2006, human;
Perry et al. 2012, sheep; Raheem et al. 2013, sheep) and also produced by the cumulus and granulosa cells of ovarian follicles (Kimura et al. 2002, pig; Schoenfelder \& Einspanier 2003, cow; Chavoshinejad et al. 2014, sheep). The role of HA in reproductive biology and clinical applications is gaining increasing recognition. HA's expansion of cumulus cells at ovulation (Salustri et al. 1989; mouse) and induction of cervical ripening during parturition (El Maradny et al. 1997, rabbit; Straach et al. 2005, mouse) are well documented. Treatment of ovariectomised mice with progesterone increased uterine HA concentration (Maioral et al. 2016). We and others have shown that the expression of HA synthases is influenced by ovarian steroid hormones having a differential effect on the expression of specific HAS and production of different size HAs during reproductive cycle and at parturition (Afify et al. 2006, Teixeira Gomes et al. 2009; mouse, Raheem et al. 2013). In addition, a range of growth factors, such as epidermal growth factor (Pienimaki et al. 2001) and transforming growth factor- $\beta$ (Pasonen-Seppanen et al. 2003), and cytokines, such as interleukin 1- $\beta$ (Oguchi \& Ishiguro 2004) and interferon gamma (Campo et al. 2006), as well 
Table 1 Concentration of hyaluronan in fluids and tissues of the reproductive system.

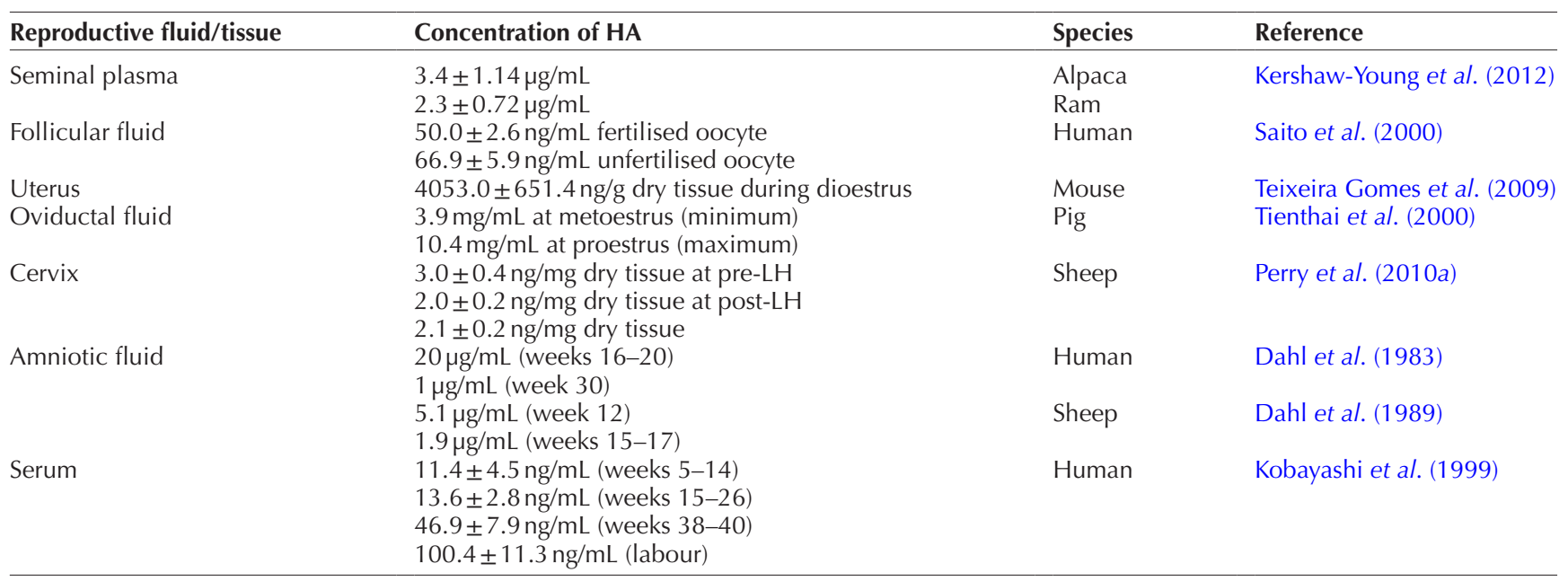

as local mediators such as prostaglandins (Sussmann et al. 2004) affect HAS expression. The actions of HA are mediated through its cell surface receptors CD-44 and RHAMM involving MAP kinases and Akt signalling (Straach et al. 2005, Kultti et al. 2010). Moreover, HA is expressed at different stages of pre-implantation embryo development (Marei et al. 2013, cow). Recently, HA has attracted more interest because its addition to embryo culture media seems to benefit in vitro fertilisation (IVF) and embryo transfer (Palasz et al. 1993; cow, mouse, Palasz et al. 2006; cow, Choudhary et al. 2007; mouse, Dattena et al. 2007; sheep, Hazlett et al. 2008; human, Hambiliki et al. 2010; human, Nakagawa et al. 2012; human).

The HA system includes hyaluronan synthases (HAS), HA-degrading enzymes (hyaluronidases; HYALs) and HA receptors. In this review, we shall explain the roles and regulation of the HA system in mammalian reproduction with particular emphasis on pre-implantation embryo development and embryo implantation.

\section{HA turnover and signalling}

$\mathrm{HA}$ is synthesised by three different but related transmembrane enzymes named hyaluronan synthases (HAS1-3) (Prehm 1984), which produce different size HAs with diverse biological functions (Itano et al. 1999, Stern et al. 2006). The HAS genes have promoters reacting to common transcriptional signals in addition to their own specific responses (reviewed in Tammi et al. 2011). HAS2 synthesises HA of higher molecular weight than HAS1, in the range of $>2 \times 10^{6} \mathrm{Da}$ (Itano et al. 1999), whereas HAS3 synthesises HA of low molecular weight $\left(1 \times 10^{5}-1 \times 10^{6} \mathrm{Da}\right)$ and represents the most active isoform of HAS. Normally, HA turnover in the body is quite constant and consistently rapid. Onethird of the $15 \mathrm{~g}$ of $\mathrm{HA}$ in the human is replaced on a daily basis (Stern 2004). As formulated by Stern (2003, 2004), a sequence of enzymatic reactions by HYALs cleave high-molecular-weight $\mathrm{HA}$ at the $\beta-\mathrm{N}$-acteyl linkage, progressively degrading $\mathrm{HA}$ by generating smaller fragments. There are six HYAL isoforms in the human genome, HYAL1, HYAL2, HYAL3, HYAL4, HYALP1, and sperm adhesion molecule 1 (SPAM1) (also known as PH20) (Csoka et al. 1999). HYAL1 and 2 are the most important isoforms involved in $\mathrm{HA}$ degradation and catabolism in somatic cells (Bastow et al. 2008). HYAL2 is a glycosylphosphatidylinositol-anchored enzyme attached to the external surface of the plasma membrane and expressed in many tissues (Lepperdinger et al. 2001). It has a specific binding capacity for the high-molecular-weight $\mathrm{HA}$, cleaving it to fragments of $\sim 20 \mathrm{kDa}$ (about 50 disaccharides) (Stern et al. 2006). HYAL1 utilises HA of any size as a substrate to generate tetrasaccharides (4-8 saccharides in size) (Frost et al. 1997). HYAL3 and HYAL4 lack hyaluronidase activity and seem to play a non-significant role in constitutive HA degradation (Harada \& Takahashi 2007, Kaneiwa et al. 2012). Similarly, HYALP1 that is present in mouse testis does not degrade HA (Reitinger et al. 2007). The role of SPAM1 is discribed later in fertilisation paragraph.

$\mathrm{HA}$ interacts with cells through its receptors, which include cluster domain 44 (Aruffo et al. 1990, CD44) and receptor for HA-mediated motility (Turley et al.2002, RHAMM). CD44 has been detected in various segments of the reproductive tract in mouse (Kennel et al. 1993), cow (Bergqvist et al. 2005a), sheep (Perry et al. 2010a), mare (Rodriguez et al. 2011) and human (López et al. 2013) under normal physiological conditions. It has also been detected in cow (Furnus et al. 2003), mouse (Matsumoto et al. 2004) and human (Campbell et al. 1995) embryos. Interaction between HYAL2 and CD44 facilitates the endocytosis of HA, which undergoes further degradation by lysosomal HYAL1 into smaller HA fragments (Lepperdinger et al. 2001).

In addition to its function as an adhesion molecule, there is evidence showing that CD44 is a potent signalling molecule. Many studies have shown that HA-CD44 
interaction can initiate several signalling events under physiological or pathological conditions such as oocyte maturation and cancer pathogenesis (Schoenfelder \& Einspanier 2003, Kimura et al. 2007, Toole 2009, Yokoo et al. 2010, Marei et al. 2012, Bourguignon \& Bikle 2015, Misra et al. 2015). HA-mediated cell surface signalling through CD44 is usually initiated by low-molecular-weight HA or HA-oligosaccharides resulting in cell migration or cell proliferation (Lee \& Spicer 2000). HA-CD44 interaction may also stimulate intracellular signalling through extracellular regulated kinase (ERK), phosphoinositide 3-kinase (P13K), Rac and Ras in various cell types (Kothapalli et al. 2008, Pure \& Assoian 2009). Although many studies on HACD44 signalling focus on cancer, HA-CD44 signalling is also observed under physiological conditions. A study from our laboratory showed that small HA fragments of $20 \mathrm{kDa}$ produced by treatment of bovine embryos with HYAL2 caused increased phosphorylation of mitogen-activated protein kinase MAPK1/3 signalling, resulting in increased blastocyst formation and quality, characterised by higher cell numbers. This effect was abrogated with the inhibition of CD44 (Marei et al. 2013). Another study also showed signalling by HA in human placenta through MAPK1/3 and PI3K pathways, which enhanced trophoblast growth and invasion and possibly placenta angiogenesis (Zhu et al. 2013a). Even though this study did not show that the signalling was through HA binding to CD44, it is likely to be through HA-CD44 because CD44 is the major receptor for HA, and earlier studies have shown the expression of CD44 in the human trophectoderm (Campbell et al. 1995) and trophoblast (Goshen et al. 1996), where it was proposed to play a significant role in placenta angiogenesis.

RHAMM (otherwise known as CD168) is alternatively spliced; hence, different isoforms of the protein were found both on the cell surface and intracellularly (cytoplasm, cytoskeleton, mitochondria, nucleus and nucleolus) (Turley et al. 2002). Intracellular RHAMM interacts with several signalling and cytoskeletal proteins, including $\mathrm{Src}$ through its interaction with microtubules and actin filaments (Assmann et al. 1999). Although RHAMM is not essential for embryo viability (Tolg et al. 2003), it has been found to play a profound role in several relevant cellular events, such as mitosis, cell proliferation and migration (Turley et al. 2002). RHAMM is highly expressed in the G2/M phase of the cell cycle, thus controlling mitosis (Mohapatra et al. 1996, Assmann et al. 1999). Deletion of the RHAMM C-terminus results in impaired spindle orientation in the dividing granulosa cells, folliculogenesis defects and subsequent female hypofertility in mice (Li et al. 2015). RHAMM knockdown results in the downregulation of several pluripotency markers in hESC, induction of early extraembryonic lineages, loss of cell viability and changes in hESC cycle suggesting its major roles in the maintenance of human embryonic stem cell pluripotency and cell viability (Choudhary et al. 2007). RHAMM protein and mRNA are expressed at all stages of human pre-implantation embryo development from 2-cell to blastocyst (Choudhary et al. 2007). The relative expression of RHAMM increased transiently from 4-cell to 8- to 12-cell stage embryos and then remained static in morula and early blastocyst, but significantly increased in expanded blastocysts (Choudhary et al. 2007). The same was confirmed in bovine embryos where mRNA for RHAMM/IHABP (intracellular HA binding protein) where the highest expression was seen in the expanded blastocyst (Stojkovic et al. 2003). Moreover, Ozbilgin and coworkers reported spatiotemporal expression of RHAMM protein in mouse endometrium during the oestrous cycle and peri-implantation period, suggesting its possible role in endometrial receptivity (Ozbilgin et al. 2012). Inhibition of RHAMM signalling by culture of sheep embryos in the presence of antiRHAMM antibody resulted in the arrest of the embryo development at the 6- to 8-cell stage (unpublished data). Considering the co-presence of HA, CD44 and RHAMM in the reproductive system, it is highly likely that they work together to support mitotic activity in the developing embryos ensuring the development of blastocysts with high cell numbers.

\section{Hyaluronan in the ovarian follicle}

A significant portion of the ECM of the ovarian follicles consists of HA (Irving-Rodgers \& Rodgers 2005). HA serves both as a structural component of ovarian follicles and in signalling cascades leading to oocyte maturation and ovulation (Rodgers et al. 2003, Kimura et al. 2007). In mice, both oocytes and cumulus cells produce HA during folliculogenesis (Salustri et al. 1992, Ueno et al. 2009). Indeed, denuded oocytes produce increasing amount of HA during culture, which was suggested to be involved in the enlargement of the perivitelline space in mouse oocytes (Ueno et al. 2009). The granulosa cell layer of the mouse antral follicle is capable of HA synthesis (Salustri et al. 1992). HA was also detected in the extracellular matrix of rat granulosa and theca cell layers of primary and more advanced follicles (Takahashi et al. 2014). HAS1 is the dominant HAS protein in theca cells of swine ovaries and may be responsible for an increase in the HA concentration of follicular fluids in atretic follicles (Miyake et al. 2009) containing macrophages expressing CD44 as a phagocytic receptor involved in phagocytosis of the apoptotic granulosa cells (Miyake et al. 2006). In sheep ovaries, we recently reported the expression of HAS and CD44, which were mainly localised in the granulosa cells (GCs) (Chavoshinejad et al. 2014). Large-size HA produced by the follicular cells contributes to the osmotic gradient of the antral follicle resulting in the accumulation of the follicular fluid and antrum formation (Clarke et al. 2006; cow, Rodgers \& Irving-Rodgers 2010). This osmotic gradient across the 
basal lamina restricts the movement of molecules above $100 \mathrm{kDa}$ from the theca capillaries into the follicular fluid in healthy follicles (Irving-Rodgers et al. 2002; cow, Rodgers \& Irving-Rodgers 2010). It was reported that the LH surge permeabilises the blood barrier of the follicle, and serum glycoproteins in the inter- $\alpha$-inhibitor family (lol) can then enter the antral cavity (Hess et al. 1999; mouse, Rodgers et al. 2003; cow). However, it is now evident that the family of $|\alpha|$ molecules can freely cross the blood-follicle barrier; follicular fluid collected at any stage of folliculogenesis can be successfully used instead of serum to form expanded cumulus ECM in pig (Nagyova 2015); and covalent binding between hyaluronan and heavy chains of $|\alpha|$ is essential for the expansion of the cumulus cell mass before ovulation (Chen et al. 1996; mouse, Nagyova et al. 2004; pig). Using cultures of sheep granulosa cells, we have shown that reproductive hormones differentially regulate HAS2, HAS3 and CD44 in ovaries (Chavoshinejad et al. 2014). Oestradiol, when combined with IGF-1, insulin and $\mathrm{FSH}$, stimulated HAS2 mRNA expression, which is essential for cumulus cell expansion prior to ovulation. Oestradiol and LH had complementary effects in increasing HAS3 and CD44 mRNA expression in the granulosa cells, an event that occurs during ovulation. Interestingly, high HAS3 and CD44 were detected in the corpus luteum, indicating a pattern of expression in the ovaries during the oestrous cycle. This may suggest a shift from production of large-size HA during follicular maturation and cumulus cell expansion (stimulated by E2, IGF-1 and FSH) to a smaller-size HA produced by HAS3 after the LH surge. Low-molecular-weight HA molecules have been linked with inflammatory processes and angiogenesis (Collins et al. 2011, Rayahin et al. 2015), which are characteristic of the follicles during ovulation (Richards et al. 2002, Blundell et al. 2003) and corpus luteum formation (Skarzynski et al. 2013, Berisha et al. 2015).

\section{Cumulus cell expansion and oocyte maturation}

Mammalian oocytes are surrounded by multiple layers of cumulus cells, together known as the cumulus-oocyte complex (COC). The cumulus oophorus supports oocyte maturation, ovulation and fertilisation (Magier et al. 1990, Tanghe et al. 2002). Before ovulation, the cumulus oophorus contributes to the control of cytoplasmic maturation and meiotic arrest (El-Hayek \& Clarke 2016, Macaulay et al. 2016). During ovulation, it facilitates oocyte movement into the oviduct (Akison et al. 2012, mouse) and shortly after ovulation, it participates in the complex mechanisms controlling the access of spermatozoa to the oocyte (Russell et al. 2016).

It has been demonstrated that cumulus cell expansion is a prerequisite for ovulation and may also reflect the competence of such oocytes after fertilisation (Chen et al. 1993). Many related studies showed HA to be the main component of cumulus expansion in the COCs (reviewed by Nagyova 2015). Cumulus expansion leads to the detachment of the oocyte from the follicular wall and interruption of the gap junctions between the cumulus cells and the oocyte (Sela-Abramovich et al. 2005). Reduced cGMP transfer from the cumulus cells to the oocyte leads to a decline in cAMP concentrations in the oocyte and resumption of oocyte nuclear maturation (Sanchez \& Smitz 2012). cGMP inhibits phosphodiesterase 3A, which maintains a high cAMP concentration in the immature oocyte during follicular growth (Norris et al. 2009), which is essential for maintaining arrest at the prophase of the first meiotic division until the preovulatory LH surge (Downs et al. 1989).

The preovulatory surge of $\mathrm{LH}$ activates HAS2 expression leading to the production of high-molecularweight HA by the cumulus cells; water absorbed by the HA results in the expansion of the COC (Saito et al. 2000, Stock et al. 2002). HA secreted by the mouse cumulus oophorus is detectable between $2 \mathrm{~h}$ and $18 \mathrm{~h}$, peaking at 4-10 h after the LH surge (Tirone et al. 1997, Zhuo \& Kimata 2001). In mice, this HA-rich matrix is organised into a cross-linked network through the cooperative action of $|\alpha|$, pentraxin-3 and TSG-6 (Sato et al. 2001, Fulop et al. 2003, Salustri et al. 2004) to gain a stabilised viscoelastic state that is required to facilitate the transfer of the oocyte to the oviduct for fertilisation (Salustri et al. 1999). However, a recent report showed that binding of TSG-6 to HA does not play a major role in the stabilisation of the cumulus cell matrix in mice (Briggs et al. 2015).

In pigs, COCs cultured in the presence of an $\mathrm{HA}$ synthesis inhibitor (6-diazo-5-oxo-1-norleucine) or HYAL failed to expand at all (Yokoo et al. 2010). Our studies in sheep also revealed that the formation of large-molecular-weight $\mathrm{HA}$ is essential for cumulus cell expansion (Marei et al. 2012). HAS2 and CD44 expression in bovine cumulus cells were found to be potential markers of oocyte competence (Assidi et al. 2008), and increased CD44 in follicular fluid was associated with good-quality oocytes (Ohta et al. 2001). The localisation of CD44, the major cell surface receptor for HA in cumulus cells (Kimura et al. 2002), suggests that HA-CD44 interaction may also be a likely player in oocyte maturation. HA-CD44 interaction regulates the tyrosine phosphorylation of Connexin 43 (the major gap junction protein found in the COCs), which leads to the closure of the gap junction and subsequent activation of maturation promotion factor (MPF) activity (Sato \& Yokoo 2005). The latter brings about resumption of meiosis in oocytes that have been arrested in meiotic prophase I until shortly before ovulation. Apparently, this activation occurs regardless of the structural expansion of cumulus cells as inhibition of cumulus cell expansion by HYAL2 did not affect further fertilisation and embryo development (Marei et al. 2012). On the other hand, inhibition of HA synthesis by 4-methylumbelliferone 
during in vitro maturation completely inhibited the development to the blastocyst stage, an effect which was partially alleviated by the addition of exogenous HA (Marei et al. 2012). This further emphasises the importance of HA signalling during oocyte maturation.

\section{Sperm-related functions}

$\mathrm{HA}$ is expressed in various segments of the male reproductive tract, including the epididymis, seminal vesicles, prostate and Cowper's gland and with traces in the testes (Tammi et al. 1994). The accessory sex glands provide the fluid medium necessary for nourishment and transportation of spermatozoa through the reproductive tract. HA is a component of the seminal plasma in ram and alpaca (Kershaw-Young et al. 2012) and may be responsible for the viscosity of the seminal plasma as observed in Ilama and alpaca (Bravo et al. 2000). Sakairi and coworkers (2007) reported the presence of $\mathrm{HA}$ in the seminal vesicles of immature pigs, without investigating further its particular roles. However, they speculated that it may contribute to the regulation of homeostasis rather than sperm functioning. Studies in mice suggest HA involvement in spermatogenesis (Thakur et al. 2006), even though the mechanism still remains to be clarified. HA induces sperm capacitation (Tienthai et al. 2004, Tienthai 2015) by the activation of membrane-associated adenylate cyclase (Fernandez \& Cordoba 2014), and it also enhances the acrosome reaction in bovine (Gutnisky et al. 2007), and porcine (Suzuki et al. 2002) without necessarily modifying the sperm nuclear condensation and morphology, possibly by decreasing the formation of vacuoles in the sperm head (Montjean et al. 2012). In dog spermatozoa, HA accelerates the calcium influx into the sperm cytoplasm and increases lactate dehydrogenase activity and cAMP production, provoking capacitation (Kawakami et al. 2006). HA may also help to prevent polyspermy during in vitro fertilisation as well as supporting blastocyst development (Kano et al. 1998) and quality by reducing apoptosis (Opiela et al. 2014). Supplementation of HA to human sperm in the swim-up procedure increased the sperm motility and reduced the number of sperm with DNA damage (Saylan \& Duman 2016).

One of the criteria by which spermatozoa are assessed is their progressive motility. In artificial insemination where semen is frozen and stored for future use, the viability of spermatozoa is greatly affected by the reduction in motility and membrane stability during cryopreservation (Critser et al. 1988). However, this impairment could be overcome by the addition of HA to the semen diluent. HA supplementation of the diluent helps to preserve post-thaw viability of boar spermatozoa in vitro and maintains the membrane stability after cryopreservation (Pena et al. 2004, Qian et al. 2016). Similar results were found in dogs (Prinosilova et al. 2009). Likewise in human, HA has been proposed to enhance sperm motility (Ghosh et al. 2002) through phosphorylation of proteins that include HA-binding protein (Ranganathan et al. 1995).

Hyaluronan-binding protein 1 (HABP1), a $68 \mathrm{kDa}$ glycoprotein, was detected on spermatozoa of cattle, buffalo, rat and human (Ranganathan et al. 1994, Bharadwaj et al. 2002, Ghosh et al. 2002, Ghosh \& Datta 2003). It participates in sperm-oocyte interaction (Ghosh et al. 2007) through its mannose residues (Ghosh \& Datta 2003). A reduction in the level of HABP1 is associated with loss of sperm motility (Ghosh et al. 2002), the mechanism that may be attributed to the ability of HABP1 to modulate sperm-oocyte interaction even in sub-fertile spermatozoa (Ghosh et al. 2007). The number of spermatozoa bound to an oocyte was reduced significantly in the presence of D-mannosylated albumin, the universal blocker of sperm-oocyte interaction, and this effect could be reversed by the addition of purified recombinant HABP1 (Ghosh et al. 2007).

The correlation of HABP1 with sperm motility initiated the development and use of sperm HA-binding assay (sHABA) in assessing the sperm viability in fertility clinics (Huszar et al. 2003). sHABA has proved useful in selecting spermatozoa with a high DNA integrity and morphology and may sometimes be used as a screening test for sperm quality before IVF (Worrilow et al. 2013). However, its use remains controversial as sHABA does not predict freeze-thawing sperm survival (Boynukalin et al. 2012), and it does not predict the pregnancy rates either in intrauterine insemination (Yogev et al. 2010) or IVF (Ye et al. 2006, Boynukalin et al. 2012).

Intracytoplasmic sperm injection (ICSI) is used in clinical IVF to bypass the physiological barriers of the cumulus oophorus and the zona pellucida in the treatment of severe male infertility due to low sperm numbers or function. The selection of the sperm for injection may perhaps be promoted by HA binding as a screening technique, given that HA-bound sperm in general are fully matured and have better morphology with a reduced risk of aneuploidy or fragmented DNA (Pregl Breznik et al. 2013), which has been reported as associated with increased pregnancy and implantation rates (Worrilow et al. 2013). However, it is not a reliable test for the prediction of sperm intracellular reactive oxygen species, DNA fragmentation and DNA maturity and mitochondrial membrane potential risks and healthy spermatozoa selection (Rashki Ghaleno et al. 2016), and the result of a recent meta-analysis study has not supported its use in human ICSI cycles (BeckFruchter et al. 2016).

\section{Sperm hyaluronidases and the role of HA system in fertilisation}

Isoforms of HYAL found in sperm are SPAM1 and HYAL5. These unique hyaluronidases are located in the testis or epididymis and have been detected in mouse 
(Zhang \& Martin-DeLeon 2001, Chen et al. 2006), pig (Day et al. 2002) and human (Evans et al. 2003). It is secreted and located on the sperm surface during epididymal maturation (Deng et al. 2000, Day et al. 2002, Evans et al. 2003, Chen et al. 2006, MartinDeLeon 2006). SPAM1 is a GPI-anchored hyaluronidase (also known as PH20), which depolymerises HA into tetrasaccharide and hexasaccharide products (Kim et al. 2005, Hofinger et al. 2008, Thompson et al. 2010). It is unique among hyaluronidases, in that it shows enzyme activity at both acidic and neutral $\mathrm{pH}$, activities that appear to involve two different domains in the protein (Gmachl \& Kreil 1993, Cherr et al. 2001). Several studies have confirmed that SPAM1 is the only hyaluronidase identified to date in mammalian sperm, including the sperm of guinea pigs, rats, macaques and humans (Cherr et al. 2001, Zheng et al. 2001). It is also present in the lysosome-derived acrosome, where it is bound to the inner acrosomal membrane (Morin et al. 2010). SPAM1 is initially synthesised as a polypeptide with an apparent molecular weight of $64 \mathrm{kDa}$. During the course of sperm maturation, part of SPAM1 is processed into two fragments that are linked through disulphide bridges, such as at the $\mathrm{N}$-terminal domain of $41-48 \mathrm{kDa}$ and at the C-terminal domain of $27 \mathrm{kDa}$.

Hyal5 is exclusively expressed in the testis and the plasma and acrosomal membranes of rodent sperm (Kim et al. 2005). It is enzymatically active in the $\mathrm{pH}$ range 5-7 and inactive at $\mathrm{pH} 3$ and 4. Both Hyal5-enriched SPAM1-free soluble protein extracts and SPAM1deficient mouse sperm were capable of dispersing cumulus cells, which was inhibited by the presence of a hyaluronidase inhibitor, apigenin. These results suggest that in the mouse, Hyal5 may function principally as a 'cumulus matrix depolymerase' in the sperm penetration through the cumulus mass (Kim et al. 2005).

The concentration of HA in follicular fluid has been used to estimate the viability of oocytes for fertilisation with concentrations as high as $50 \mathrm{ng} / \mathrm{mL}$ (Saito et al. 2000) to $239.3 \mathrm{ng} / \mathrm{mL}$ (Babayan et al. 2008) being associated with fertilisation of the oocyte and embryo implantation in human.

Despite the presence of HYAL in mouse, its role in fertilisation remains uncertain. Kimura and coworkers (2009) showed SPAM1 to be required for sperm penetration through the cumulus matrix for fertilisation in mice. It was also reported to be involved in sperm-ZP binding (Myles \& Primakoff 1997, Cherr et al. 2001) and induction of the acrosome reaction (Overstreet et al. 1995, Sabeur et al. 1998). Reddy and coworkers (1980) used a hyaluronidase inhibitor in mice to clarify HYAL function in fertilisation. In their study, myochrysine, a natural inhibitor of HYAL with no effect on the acrosome reaction, inhibited fertilisation due to reduced breakdown of the COC. However, a similar effect was not observed when using oocytes devoid of follicular cells. Another study using a double knockout model confirmed that sperm serine proteases, ACR (acrosin) and/or PRSS21 (testisin), function cooperatively with SPAM1 in cumulus penetration in mice (Zhou et al. 2012). In addition, HA fragments generated by SPAM1 stimulate cytokine/chemokine production via the TLR2 and TLR4 pathways in cumulus cells of ovulated COCs, which may enhance fertilisation (Shimada et al. 2008). However, mice lacking SPAM1 and HYAL5 are fertile, indicating that the HA-degrading ability of HYAL in mouse sperm is not essential for fertilisation (Kang et al. 2010). It is also possible that SPAM-1 secreted by the oestrous uterus and oviduct, with the potential to bind to sperm during capacitation (Zhang \& Martin-DeLeon 2003, Griffiths et al. 2008) might have compensated for its absence in the sperm itself in the knockout model. In addition, the detection of functionally active HYAL5 on the surface of SPAM1-deficient spermatozoa confirmed that compensation was possibly occurring by this HYAL (Zhang et al. 2005). Moreover, HYAL2 that was reported to be present in mouse sperm (Modelski et al. 2014) may have contributed to this functional redundancy.

\section{Pre-implantation embryo development}

In cattle, HAS2 and HAS3 are expressed at all stages of early embryo development from 2-cell to blastocyst (Marei et al. 2013). We found that HAS2 mRNA expression tended to decrease with the progression to the blastocyst stage, whereas HAS3 expression was maintained. Moreover, HA receptors CD44 and RHAMM were also expressed at all stages (Furnus et al. 2003, Palasz et al. 2006, Choudhary et al. 2007).

Studies in murine, porcine and bovine have shown that HA supplementation of culture media improves embryo development, viability and blastocyst cell number in vitro (Furnus et al. 1998, Gardner et al. 1999, Jang et al. 2003, Lane et al. 2003, Toyokawa et al. 2005). $\mathrm{HA}$ has also been shown to improve the cryotolerance of blastocysts, which then leads to increased birth rates in cows (Lane et al. 2003), mice (Palasz et al. 1993) and ewes (Dattena et al. 2007). On the contrary, in a randomised clinical trial of human IVF, hyaluronan enrichment of the embryo transfer media did not have any beneficial effects on IVF outcome in terms of clinical pregnancy implantation and delivery rates, although higher birthweights occurred in the HA group (Fancsovits et al. 2015). However, the inhibition of HA synthesis by 4-methyumbelliferone (4-MU) suppressed blastocyst formation in sheep, (Marei et al. 2013) indicating the critical role of $\mathrm{HA}$ in embryo development in this species. 4-MU is a coumarin derivative that has been shown to supress HA synthesis in mammalian cell cultures (Nakamura et al. 1997). The effect seems to be reversible upon removal of 4-MU from the cell culture. The disruption of HA synthesis by 4-MU is both at the level of the substrates (UDP-GIcUA and UDP-GlcNAc) and HAS expression. 4-MU has affinity to conjugate 
with UDP-GIcUA, with reduction in the cellular pool of this substrate as well as causing downregulation of HAS2 and HAS3 (Kultti et al. 2009).

The effect of HA on embryo development seems to be HA-size dependent. HA fragments generated by HA depolymerisation by HYALs are biologically active molecules that have important functions (Stern et al. 2006). Most of these functions are receptor mediated and increase cell proliferation through binding to CD44 and RHAMM (Xu et al. 2002) incurring phosphorylation and activation of the MAPK pathway (Zhu et al. 2013a,b) and stimulation of mitosis. In cleavage-stage bovine embryos treated with HYAL2, we detected higher levels of MAPK1 and MAPK3, an increased incidence of blastocyst development and increased blastocyst quality as shown by higher total numbers of cells and trophectoderm cells (Marei et al. 2013). These effects were abrogated if CD44 was blocked (Marei et al. 2013). These data show the potential beneficial effects and importance of small-size HA in the development of pre-implantation embryos.

In vivo, early stages of embryo development in most mammals happen in the isthmus compartment of the oviduct. HA was detected in oviductal fluids collected by catheterisation during the oestrous cycle in heifers and cows (Stojkovic et al. 2002) and was shown to be highest at ovulation (Bergqvist et al. 2005b). Transcripts for HAS2 and HAS3 have been found in the oviducts of several animal species (Tienthai et al. 2003, Ulbrich et al. 2004, Mohey-Elsaeed et al. 2015). It has been noted that HAS3 expression was higher in the isthmus compared to the ampulla (Ulbrich et al. 2004, Marei et al. 2013, Mohey-Elsaeed et al. 2015) suggesting that a gradient of decreasing molecular size of $\mathrm{HA}$ is experienced during embryo development and progression down the oviduct. In support of this idea, we recently reported that infusion of Hyalovet (500-750 kDa HA) into sheep oviduct on day 2 after mating significantly reduced the incidence of blastocyst formation by day 7 and decreased insulin-like growth factors IGF2 and IGFBP2 expression in the oviduct epithelial cells. In contrast, HYAL-2 infusion increased blastocyst formation, quality and the number of hatched blastocysts and increased HSP7O expression in oviductal epithelial cells (Marei et al. 2016a). Similar opposing effects of Hyalovet and HYAL-2 were observed in in vitro-produced sheep embryos (Marei et al. 2016a). Small-sized HA has been shown to regulate the expression of IGFs (Homandberg et al. 2004) and heat shock proteins (Xu et al. 2002), which are important for early embryo development in the oviduct (Aviles et al. 2010). We concluded that the presence of large-size HA in the vicinity of developing embryos disturbs the oviductal environment and embryo development. Interestingly, HYAL-2 mRNA is expressed in sheep embryos starting from the morula stage (Marei et al. 2013). HYAL2 is also expressed in the oviduct with significantly higher levels in the isthmus as compared to the ampulla (Marei et al. 2013). We hypothesise that the small-sized HA produced by oviductal HYAL-2 supports embryo development until the morula stage as cleavage-stage embryos do not express HYAL-2 (Marei et al. 2013).

\section{Embryo implantation-contrasting data}

Synthesis of HA is increased significantly in the uterus of mice on the day of implantation (Carson et al. 1987), and HA differential expression in the human endometrium during the menstrual cycle implies its involvement in implantation. In the human uterus, peak expression of HAS and CD44 is in the mid-secretory stage (Afify et al. 2006). There is a plethora of data suggesting the beneficial roles for HA in human embryo implantation (Urman et al. 2008, Hambiliki et al. 2010, Nakagawa et al. 2012). It is thought that implantation failure could be reduced by providing a 'sticky' matrix for the embryos to attach and for this reason HA (which is also called 'magic glue' (Girish \& Kemparaju 2007), or EmbryoGlue (Hazlett et al. 2008)) is often used as a supplement in human embryo transfer medium. The presence of $\mathrm{HA}$ in mouse embryo transfer medium resulted in higher implantation and live birth rates (Gardner et al. 1999). Similarly, a Cochrane meta-analysis of clinical trials concluded that HA inclusion in embryo transfer media significantly increases clinical pregnancy rates and live birth rates (Bontekoe et al. 2014). In an attempt to develop human embryo culture media free from blood-derived additives, HA was successfully used to replace albumin as a sole macromolecule in a human embryo transfer medium and resulted in high pregnancy and implantation rates (Simon 2003). In addition, the use of HA in transfer media for human frozen embryos significantly increased the implantation rate without increasing the delivery rate (Hambiliki et al. 2010). The mechanism through which HA promotes implantation still remains uncertain. It is generally attributed to facilitating apposition and attachment of the trophectoderm to the maternal endometrium during the early stages of implantation. The role of CD44 at the blastocyst-endometrial interface during implantation was stressed in the study of Illera and coworkers (2004) in rabbits, where intrauterine infusion of anti-CD44 hindered implantation, whereas intra-peritoneal infusion of the same antibodies in the control rabbits had no effect on implantation.

On the other hand, some reports contradict the published beneficial effects of HA supplementation in transfer media for embryo transfer (Loutradi et al. 2007, Hazlett et al. 2008, Check et al. 2010). In women who failed to conceive despite at least 3 previous embryo transfers, a $25 \%$ clinical pregnancy and $14.2 \%$ delivered pregnancy were achieved using EmbryoGlue (highmolecular-weight HA produced by Vitrolife), when compared to women not using EmbryoGlue (39.2\% and $39.2 \%$ respectively) (Dietterich et al. 2007). Among 
120 cases, no statistical difference was found between clinical pregnancies in a control group compared to a test group using EmbryoGlue (38\% vs $42 \%$ ) (Chao et al. 2008). Similar results were obtained by Marek and coworkers (2004) and Chun and coworkers (2016). Routine use of EmbryoGlue in unselected patients did not significantly improve pregnancy or implantation rates after embryo transfer on day 3 or day 5 compared with standard culture media (Hazlett et al. 2008). A better understanding of the mechanism of HA's involvement in reproduction and implantation in particular will improve the prospects for developing an effective clinical intervention based upon this molecule.

Accumulation of HA resulting from the dysregulated expression of HASs or HYALs is associated with the disease. For example, failure of HA turnover in HYAL2 knockout mice resulted in HA accumulation and severe cardiopulmonary dysfunction (Chowdhury et al. 2013). Enhanced synthesis of HA by proinflammatory cytokines has been associated with renal and rheumatoid diseases (Dahl et al. 1985, Manicourt et al. 1993, Feusi et al. 1999). Similarly, dysregulation of HA metabolism is a typical feature of diabetes (Nieuwdorp et al. 2007) or endometrial cancer (Afify et al. 2005, Nykopp et al. 2010). HA dysregulation may be associated with unexplained infertility (Altmäe et al. 2010), and most relevant here, HA accumulation in the uterus has been linked with early embryo loss including spontaneous abortion (Camenisch et al. 2000, Cordo-Russo et al. 2009). Studies in pregnant mice reported the disappearance of $\mathrm{HA}$ at the maternalembryo interface at days 5-7 of pregnancy (Brown \& Papaioannou 1992, 1993, Martins et al. 2003). HYAL-2 is also expressed in trophoblast giant binucleate cells and the multinucleated syncytia of sheep placentomes commencing on day 16 of gestation (Dunlap et al. 2005), coinciding with the attachment and perhaps contributing to the clearance of $\mathrm{HA}$ at the implantation sites. In line with these reports, inhibition of HA by the infusion of 4-MU into the sheep uterus on day 14 after natural mating enhanced embryo implantation (Marei et al. 2016b). Therefore, further prospective randomised clinical trials are essential for a robust conclusion to be made concerning the potential beneficial effects of HA pathway manipulation for women undergoing embryo transfer (Loutradi et al. 2008).

\section{Cervix ripening/relaxation}

The cervix is the entrance to the uterus. In most species especially sheep, it forms a rigid and tightly closed non-distensible structure, which is necessary to prevent access of microorganisms into the uterus. However, a pathway through the cervix is essential under two conditions. One is for the passage of sperm after coitus and secondly at parturition. The cervical connective tissue is mainly composed of collagen, $\mathrm{HA}$ and proteoglycan (Leppert 1992). The HA content of the cervix varies with the stage of oestrus cycle, with the highest and lowest values during pre-LH surge and post-LH surge periods respectively, whereas the value in the luteal stage is intermediate (Perry et al. 2010a).

Cervical remodelling at parturition can be divided into cervical softening (a gradual process that occurs several days (gestation day 12 in the rat; Harkness \& Harkness 1959) or weeks prior to parturition (during the second trimester of pregnancy in the human; Leppert 1995)) and cervical ripening phases. Cervical ripening, which occurs in the hours (rodents) and days (women) preceding parturition, is characterised by hydration and further growth, decreased tensile strength, increased cervical secretions and lubrication, disorganisation of collagen fibrils, further changes in the composition of GAGs and infiltration of inflammatory cells. These are influenced by the local endocrine milieu, as well as interactions and cross-talk between the cellular components (stroma and epithelium), inflammatory cells and extracellular matrix (Straach et al. 2005).

Regulation of HA synthesis in the cervix is a conserved process in mammalian species. Hyaluronan content of cervix increases markedly during late pregnancy in human, sheep, guinea pig, rabbit and rat (Downing \& Sherwood 1986, Anderson et al. 1991, Rajabi et al. 1992, El Maradny et al. 1997). The HA level increases from $19 \%$ of total GAG in early pregnancy to $71 \%$ at term (Akgul et al. 2012) and the majority of cervical $\mathrm{HA}$ in mice is synthesised by HAS2 (Akgul et al. 2014). Uchiyama and coworkers (2005) reported peak levels of HAS1 and HAS2 mRNA expression in mouse cervix at delivery. HAS2 has also been identified to be specifically upregulated in women at labour relative to pregnant women not in labour (Straach et al. 2005). HAS2 produces high-molecular-weight HA, which may facilitate the ripening of the cervix by increasing the water content and cytokines (interleukin 8) of the cervix, possibly due to its hydrodynamic and viscoelastic properties (El Maradny et al. 1997). Despite this, more recent work by Akgul and coworkers on HAS knockout mice has revealed that HA is not necessary for the increased cervical distensibility during late gestation (Akgul et al. 2014).

Artificial insemination (AI) is one of the greatest technologies devised for genetic improvement of animals. The success of Al, however, depends greatly on the ease of introducing the prepared spermatozoa through the cervix into the uterus with the aid of a catheter (Kaabi et al. 2006). As intracervical application of HA has the potential to improve cervical dilation, there may also be a very practical application for HA during artificial insemination in mammals (Perry et al. 2010b). 


\section{Cryopreservation of embryos and in vitro embryo production}

In cattle, one of the major factors limiting the usefulness of IVF is the problem of cryopreservation of bovine oocytes. This process is frequently accompanied by intracellular ice formation and generation of reactive oxygen species that subsequently lead to degeneration during thawing, and hence, a high chance of fertilisation failure. Addition of $\mathrm{HA}$ to the culture medium may perhaps alleviate this problem, although it remains to be seen whether the observations of improvements in embryo cryopreservation can be replicated in oocytes. HA-supplemented media enhances blastocyst yield, improves survival after blastocyst vitrification and promotes post-transfer survival of fresh morula and blastocyst stage embryos as compared to those in medium supplemented with bovine serum albumin (Block et al. 2009). HA improves the developmental capacity of bovine embryos under in vitro conditions and is warranted as a culture supplement for in vitro production of bovine embryos, particularly if they are to be cryopreserved (Stojkovic et al. 2002). In humans, a high level of $\mathrm{HA}$ in the embryo transfer medium was found to improve the clinical pregnancy rate and chances of attachment of frozen-thawed embryos (Hambiliki et al. 2010), possibly by reducing apoptosis and induction of heat shock protein. Small fragments of $\mathrm{HA}$ induce heat shock protein and suppress apoptosis in vitro (Xu et al. 2002). Similar effects promoting cryosurvival have been reported in stem cells where both post-thaw viability and phenotypic characteristics are improved by HA (Turner et al. 2012).

\section{Integral model to explain the reproductive functions of HA}

It is apparent that most of the signalling effects of HA have been attributed to low-molecular-weight HA; however, it becomes a subject of contention whether low or high molecular weight HA is more beneficial (Camenisch \& McDonald 2000). HA's biological functions depend upon its molecular weight. Interestingly, low- and highmolecular-weight HAs have opposing functions. The functions of high-molecular-weight $\mathrm{HA}$ are premised on its physical properties of being hygroscopic, space filling, antiangiogenic and immunosuppressive, impeding differentiation and causing cell cycle arrest (Fraser et al. 1997, Necas et al. 2008). On the contrary, low-molecularweight HA is associated with pro-inflammatory, angiogenic and anti-apoptotic effects, facilitating cellto-cell interaction, cell proliferation and HA-receptormediated signalling (Toole 2004, Matou-Nasri et al. 2009).

As far as reproduction is concerned, we need to consider the anatomical component and physiological status of the tissue in context. Clearly, high-molecularweight HA may be required at a particular point in time by a reproductive tissue, whereas the next phase of the same tissue's differentiation may require lowmolecular-weight HA. Low-molecular-weight HA may be produced directly by HAS3 or through cleavage of

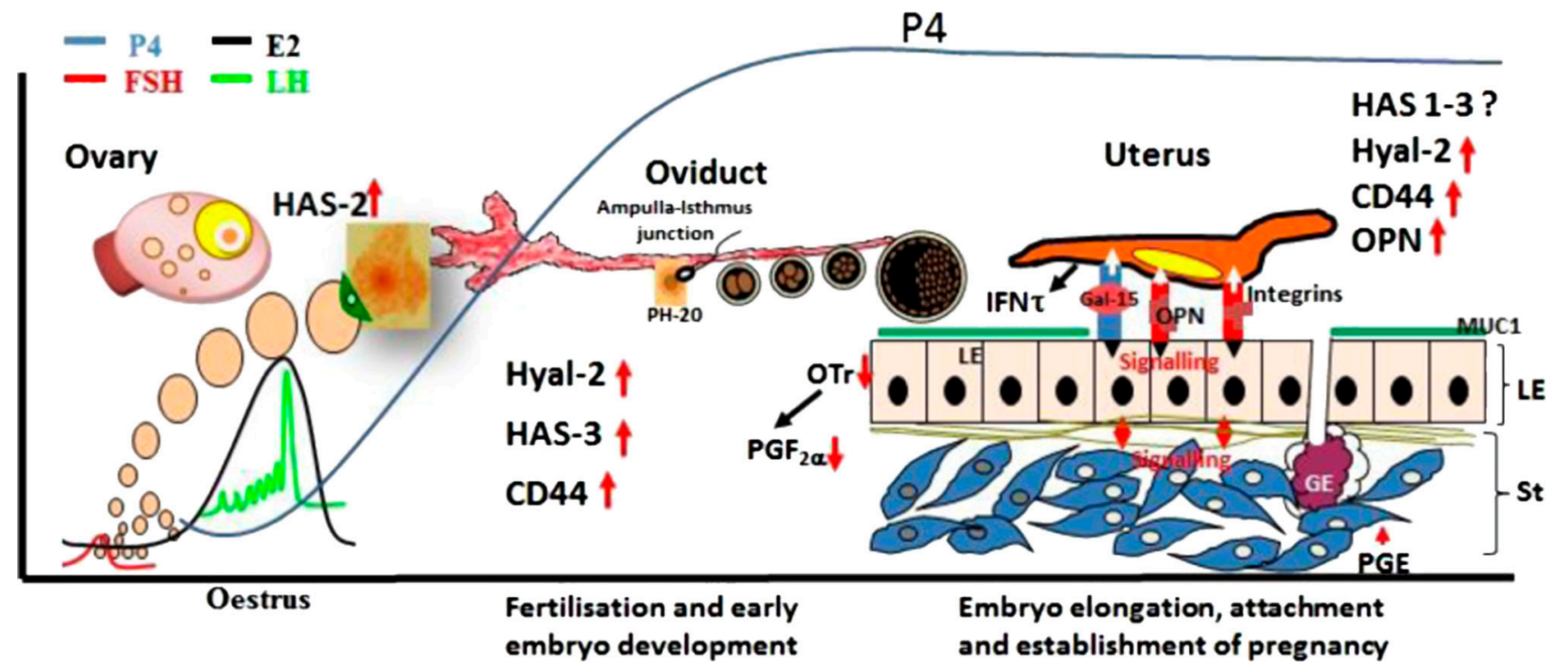

Figure 1 Model of the regulation of HA biosynthesis, degradation and function in the reproductive system. We hypothesise that at least in ungulates, steroid hormones orchestrate a sequential expression pattern for HA of different sizes in the reproductive system, with oestradiol (E2) inducing expression of HAS-2 resulting in the production of large-molecular-weight HA to support ovulation and fertilisation, followed by the progesterone (P4)-dominated phase, which upregulates CD44 expression and stimulates small-size HA production by HAS3 and HA fragments Hyal-2. Hyal-2 and HA fragments support early embryo development and induce the expression of adhesion molecules and signalling cascades required for the attachment of the blastocyst to the uterine luminal epithelium (LE) and establishment of pregnancy. FSH, follicle-stimulating hormone; GE, glandular epithelium; LH, luteinising hormone; IFNt, interferon tau; MUC1, mucin 1; OPN, osteopontin; OTr, oxytocin receptor; PG"2a, prostaglandin F2 alpha; PGE, prostaglandin E; St, uterine stroma cells. 
high-molecular-weight HA by HYAL i. Therefore, we wish to emphasise that the prediction of $\mathrm{HA}$ function resulting from HAS1, HAS2 or HAS3 is difficult without taking into consideration the HA-degrading activity of HYALs. The functions of HA therefore depend not only upon its intrinsic properties but also upon a complex balance of polymerisation by HASs, depolymerisation by HYALs and interactions with HA receptors and HA-binding proteins as well as other intracellular and extracellular components such as growth factors and cytokines.

Based upon our work and that of others, as outlined previously, we now propose a model that takes into account the integrated functions of $\mathrm{HA}$ according to size, the location of HA in different places throughout the reproductive tract and the timing of its presence, relative to female reproductive cycles and the prevailing hormonal environment at any given moment (Fig. 1). Such model is primarily applicable to ungulate species such as sheep and cow. Nevertheless, the three genes encoding hyaluronan synthases are highly conserved in vertebrates, and the simple structure of $\mathrm{HA}$ is conserved throughout all mammals. This implies that a similar pattern of expression and regulation may be generalised to other mammals.

In conclusion, we have presented evidence from a range of mammalian species for the central role of $\mathrm{HA}$ in key events in reproduction. HA is ubiquitous; however, its actions at different locations within the reproductive tract depend critically upon its size, which is controlled by the balance of synthesis by one of three isoforms, degradation, which is undertaken principally by two hyaluronidase isoforms, together with a sperm-specific isoform around fertilisation, and its signalling pathways, which occur via CD44 and RHAMM. Superimposed upon these variables is the cyclicity inherent in female mammalian reproduction, with steroid hormones affecting the synthetic enzymes and thereby tilting the balance of small- or large-molecular-weight HA being predominant. A better understanding of how the different components are orchestrated will provide opportunities for correction of pathology and promotion of normal fertility or contraception in a range of situations and species. In particular, assisted conception in animal species, rare species preservation and human IVF will benefit from improved reagents and strategies to control implantation.

\section{Declaration of interest}

The authors declare that there is no conflict of interest that could be perceived as prejudicing the impartiality of the research reported.

\section{Funding}

This work was supported by the BBSRC New Investigator Award (BB/G008620/1) and BBSRC Follow on Fund (BB/L024373/1) to Dr Ali Fouladi-Nashta and Prof Geraldine Hartshorne.

\section{References}

Afify A, Craig S, Paulino A \& Stern R 2005 Expression of hyaluronic acid and its receptors, CD44s and CD44v6, in normal, hyperplastic, and neoplastic endometrium. Annals of Diagnostic Pathology 9 312-318. (doi:10.1016/j.anndiagpath.2005.07.004)

Afify AM, Craig S \& Paulino AF 2006 Temporal variation in the distribution of hyaluronic acid, CD44s, and CD44v6 in the human endometrium across the menstrual cycle. Applied Immunohistochemistry and Molecular Morphology 14 328-333. (doi:10.1097/00129039-200609000-00012)

Akgul Y, Holt R, Mummert M, Word A \& Mahendroo M 2012 Dynamic changes in cervical glycosaminoglycan composition during normal pregnancy and preterm birth. Endocrinology 153 3493-3503. (doi:10.1210/en.2011-1950)

Akgul Y, Word RA, Ensign LM, Yamaguchi Y, Lydon J, Hanes J \& Mahendroo M 2014 Hyaluronan in cervical epithelia protects against infection-mediated preterm birth. Journal of Clinical Investigation 124 5481-5489. (doi:10.1172/JCI78765)

Akison LK, Alvino ER, Dunning KR, Robker RL \& Russell DL 2012 Transient invasive migration in mouse cumulus oocyte complexes induced at ovulation by luteinizing hormone. Biology of Reproduction $\mathbf{8 6} 125$. (doi:10.1095/biolreprod.111.097345)

Altmäe S, Martínez-Conejero JA, Salumets A, Simón C, Horcajadas JA \& Stavreus-Evers A 2010 Endometrial gene expression analysis at the time of embryo implantation in women with unexplained infertility. Molecular Human Reproduction 16 178-187. (doi:10.1093/molehr/gap102)

Anderson JC, Raynes JG, Fitzpatrick RJ \& Dobson H 1991 Increased hyaluronate synthesis and changes in glycosaminoglycan ratios and molecular weight of proteoglycans synthesised by cultured cervical tissue from ewes at various stages of pregnancy. Biochimica et Biophysica Acta 1075 187-190. (doi:10.1016/0304-4165(91)90250-K)

Aruffo A, Stamenkovic I, Melnick M, Underhill CB \& Seed B 1990 CD44 is the principal cell surface receptor for hyaluronate. Cell 61 1303-1313. (doi:10.1016/0092-8674(90)90694-A)

Assidi M, Dufort I, Ali A, Hamel M, Algriany O, Dielemann S \& Sirard MA 2008 Identification of potential markers of oocyte competence expressed in bovine cumulus cells matured with follicle-stimulating hormone and/or phorbol myristate acetate in vitro. Biology of Reproduction 79 209-222. (doi:10.1095/biolreprod.108.067686)

Assmann V, Jenkinson D, Marshall JF \& Hart IR 1999 The intracellular hyaluronan receptor RHAMM/IHABP interacts with microtubules and actin filaments. Journal of Cell Science 112 (Part 22) 3943-3954.

Aviles M, Gutierrez-Adan A \& Coy P 2010 Oviductal secretions: will they be key factors for the future ARTs? Molecular Human Reproduction 16 896-906. (doi:10.1093/molehr/gaq056)

Babayan A, Neuer A, Dieterle S, Bongiovanni AM \& Witkin SS 2008 Hyaluronan in follicular fluid and embryo implantation following in vitro fertilization and embryo transfer. Journal of Assisted Reproduction and Genetics 25 473-476. (doi:10.1007/s10815-008-9268-4)

Bastow ER, Byers S, Golub SB, Clarkin CE, Pitsillides AA \& Fosang AJ 2008 Hyaluronan synthesis and degradation in cartilage and bone. Cellular and Molecular Life Sciences 65 395-413. (doi:10.1007/s00018-007-7360-z)

Beck-Fruchter R, Shalev E \& Weiss A 2016 Clinical benefit using sperm hyaluronic acid binding technique in ICSI cycles: a systematic review and meta-analysis. Reproductive Biomedicine Online 32 286-298. (doi:10.1016/j.rbmo.2015.12.001)

Bergqvist AS, Yokoo M, Bage R, Sato E \& Rodriguez-Martinez H 2005a Detection of the hyaluronan receptor CD44 in the bovine oviductal epithelium. Journal of Reproduction and Development 51 445-453. (doi:10.1262/jrd.17010)

Bergqvist AS, Yokoo M, Heldin P, Frendin J, Sato E \& RodriguezMartinez H 2005b Hyaluronan and its binding proteins in the epithelium and intraluminal fluid of the bovine oviduct. Zygote 13 207-218. (doi:10.1017/S0967199405003266)

Berisha B, Schams D, Rodler D \& Pfaffl MW 2015 Angiogenesis in the ovary - the most important regulatory event for follicle and corpus luteum development and function in cow - an overview. Anatomia, Histologia, Embryologia 45 124-130. (doi:10.1111/ahe.12180)

Bharadwaj A, Ghosh I, Sengupta A, Cooper TG, Weinbauer GF, Brinkworth MH, Nieschlag E \& Datta K 2002 Stage-specific expression of proprotein form of hyaluronan binding protein 1 (HABP1) during spermatogenesis in rat. Molecular Reproduction and Development 62 223-232. (doi:10.1002/mrd.10135) 
Block J, Bonilla L \& Hansen PJ 2009 Effect of addition of hyaluronan to embryo culture medium on survival of bovine embryos in vitro following vitrification and establishment of pregnancy after transfer to recipients. Theriogenology 71 1063-1071. (doi:10.1016/j.theriogenology.2008.11.007)

Blundell CD, Mahoney DJ, Almond A, DeAngelis PL, Kahmann JD, Teriete P, Pickford AR, Campbell ID \& Day AJ 2003 The link module from ovulation- and inflammation-associated protein TSG-6 changes conformation on hyaluronan binding. Journal of Biological Chemistry 278 49261-49270. (doi:10.1074/jbc.M309623200)

Bontekoe S, Heineman MJ, Johnson N \& Blake D 2014 Adherence compounds in embryo transfer media for assisted reproductive technologies. Cochrane Database of Systematic Reviews 2 CD007421. (doi:10.1002/14651858.cd007421.pub3)

Bourguignon LY \& Bikle D 2015 Selective hyaluronan-CD44 signaling promotes miRNA-21 expression and interacts with vitamin D function during cutaneous squamous cell carcinomas progression following UV irradiation. Frontiers in Immunology 6 224. (doi:10.3389/fimmu.2015.00224)

Boynukalin FK, Esinler I, Guven S \& Gunalp S 2012 Hyaluronan binding assay does not predict pregnancy rates in IUI cycles in couples with unexplained infertility. Archives of Gynecology and Obstetrics 286 1577-1580. (doi:10.1007/s00404-012-2476-2)

Bravo PW, Ccallo M \& Garnica J 2000 The effect of enzymes on semen viscosity in Llamas and Alpacas. Small Ruminant Research 38 91-95. (doi:10.1016/S0921-4488(00)00142-5)

Briggs DC, Birchenough HL, Ali T, Rugg MS, Waltho JP, levoli E, Jowitt TA, Enghild JJ, Richter RP, Salustri A et al. 2015 Metal ion-dependent heavy chain transfer activity of TSG-6 mediates assembly of the cumulus-oocyte matrix. Journal of Biological Chemistry 290 28708-28723. (doi:10.1074/ jbc.M115.669838)

Brown JJ \& Papaioannou VE 1992 Distribution of hyaluronan in the mouse endometrium during the periimplantation period of pregnancy. Differentiation 52 61-68. (doi:10.1111/j.1432-0436.1992.tb00500.x)

Brown JJ \& Papaioannou VE 1993 Ontogeny of hyaluronan secretion during early mouse development. Development 117 483-492.

Camenisch TD \& McDonald JA 2000 Hyaluronan: is bigger better? American Journal of Respiratory Cell and Molecular Biology 23 431-433. (doi:10.1165/ajrcmb.23.4.f201)

Camenisch TD, Spicer AP, Brehm-Gibson T, Biesterfeldt J, Augustine ML, Calabro A Jr, Kubalak S, Klewer SE \& McDonald JA 2000 Disruption of hyaluronan synthase- 2 abrogates normal cardiac morphogenesis and hyaluronan-mediated transformation of epithelium to mesenchyme. Journal of Clinical Investigation 106 349-360. (doi:10.1172/JCI10272)

Campbell S, Swann HR, Aplin JD, Seif MW, Kimber SJ \& Elstein M 1995 CD44 is expressed throughout pre-implantation human embryo development. Human Reproduction 10 425-430.

Campo GM, Avenoso A, Campo S, Angela D, Ferlazzo AM \& Calatroni A 2006 TNF-alpha, IFN-gamma, and IL-1beta modulate hyaluronan synthase expression in human skin fibroblasts: synergistic effect by concomital treatment with FeSO4 plus ascorbate. Molecular and Cellular Biochemistry 292 169-178. (doi:10.1007/s11010-0069230-7)

Carson DD, Dutt A \& Tang J-P 1987 Glycoconjugate synthesis during early pregnancy: Hyaluronate synthesis and function. Developmental Biology 120 228-235. (doi:10.1016/0012-1606(87)90120-5)

Chao S, Schenkman E, Kim S, Kenigsberg D, Brenner S \& Moodie G 2008 The effect of embryo glue on clinical pregnancy rate in frozen embryo transfers. Fertility and Sterility 90 (Supplement) S434. Abstract 161.

Chavoshinejad R, Marei WF, Hartshorne GM \& Fouladi-Nashta AA 2014 Localisation and endocrine control of hyaluronan synthase (HAS) 2, HAS3 and CD44 expression in sheep granulosa cells. Reproduction, Fertility and Development 28 765-775. (doi:10.1071/RD14294)

Check JH, Summers-Chase D, Yuan W, Swenson K, Horwath D \& Press M 2012 'Embryo glue' does not seem to improve chances of subsequent pregnancy in refractory in vitro fertilization cases. Clinical and Experimental Obstetrics and Gynecology 39 11-12.

Chen L, Russell PT \& Larsen WJ 1993 Functional significance of cumulus expansion in the mouse: roles for the preovulatory synthesis of hyaluronic acid within the cumulus mass. Molecular Reproduction and Development 34 87-93. (doi:10.1002/mrd.1080340114)

Chen L, Zhang H, Powers RW, Russell PT \& Larsen WJ 1996 Covalent linkage between proteins of the inter-alpha-inhibitor family and hyaluronic acid is mediated by a factor produced by granulosa cells.
Journal of Biological Chemistry 271 19409-19414. (doi:10.1074/ jbc.271.32.19409)

Chen H, Griffiths G, Galileo DS \& Martin-DeLeon PA 2006 Epididymal SPAM1 is a marker for sperm maturation in the mouse. Biology of Reproduction 74 923-930. (doi:10.1095/biolreprod.105.048587)

Cherr GN, Yudin Al \& Overstreet JW 2001 The dual functions of GPIanchored $\mathrm{PH}-20$ : hyaluronidase and intracellular signaling. Matrix Biology 20 515-525. (doi:10.1016/S0945-053X(01)00171-8)

Choudhary M, Zhang X, Stojkovic P, Hyslop L, Anyfantis G, Herbert M, Murdoch AP, Stojkovic M \& Lako M 2007 Putative role of hyaluronan and its related genes, HAS2 and RHAMM, in human early preimplantation embryogenesis and embryonic stem cell characterization. Stem Cells $\mathbf{2 5}$ 3045-3057. (doi:10.1634/stemcells.2007-0296)

Chowdhury B, Hemming R, Hombach-Klonisch S, Flamion B \& TriggsRaine B 2013 Murine hyaluronidase 2 deficiency results in extracellular hyaluronan accumulation and severe cardiopulmonary dysfunction. Journal of Biological Chemistry 288 520-528. (doi:10.1074/jbc.M112.393629)

Chun S, Soe JE, Rim YJ, Joo JH, Lee YC \& Koo YH 2016 Efficacy of hyaluronan-rich transfer medium on implantation and pregnancy rates in fresh and frozen-thawed blastocyst transfers in Korean women with previous implantation failure. Obstetrics and Gynecology Science 59 201-207. (doi:10.5468/ogs.2016.59.3.201)

Clarke HG, Hope SA, Byers S \& Rodgers RJ 2006 Formation of ovarian follicular fluid may be due to the osmotic potential of large glycosaminoglycans and proteoglycans. Reproduction 132 119-131. (doi:10.1530/rep.1.00960)

Collins SL, Black KE, Chan-Li Y, Ahn YH, Cole PA, Powell JD \& Horton MR 2011 Hyaluronan fragments promote inflammation by down-regulating the anti-inflammatory A2a receptor. American Journal of Respiratory Cell and Molecular Biology 45 675-683. (doi:10.1165/rcmb.20100387OC)

Contreras-Ruiz L, de la Fuente M, Párraga JE, López-García A, Fernández I, Seijo B, Sánchez A, Calonge M \& Diebold Y 2011 Intracellular trafficking of hyaluronic acid-chitosan oligomerbased. Molecular Vision 17 279-290.

Cordo-Russo R, Garcia MG, Barrientos G, Orsal AS, Viola M, Moschansky P, Ringel F, Passi A, Alaniz L, Hajos S et al. 2009 Murine abortion is associated with enhanced hyaluronan expression and abnormal localization at the fetomaternal interface. Placenta 30 88-95. (doi:10.1016/j.placenta.2008.10.013)

Critser JK, Huse-Benda AR, Aaker DV, Arneson BW \& Ball GD 1988 Cryopreservation of human spermatozoa. The effect of cryoprotectants on motility. Fertility and Sterility 50 314-320. (doi:10.1016/S00150282(16)60079-1)

Csoka AB, Scherer SW \& Stern R 1999 Expression analysis of six paralogous human hyaluronidase genes clustered on chromosomes 3p21 and 7q31. Genomics 60 356-361. (doi:10.1006/geno.1999.5876)

Dahl LB, Hopwood JJ, Laurent UB, Lilija K \& Tengblad A 1983 The concentration of hyaluronate in amniotic fluid. Biochemical Medicine 30 280-283. (doi:10.1016/0006-2944(83)90018-2)

Dahl LB, Dahl IM, Engstrom-Laurent A \& Granath K 1985 Concentration and molecular weight of sodium hyaluronate in synovial fluid from patients with rheumatoid arthritis and other arthropathies. Annals of the Rheumatic Diseases 44 817-822. (doi:10.1136/ard.44.12.817)

Dahl LB, Kimpton WG, Cahill RN, Brown TJ \& Fraser RE 1989 The origin and fate of hyaluronan in amniotic fluid. Journal of Developmental Physiology 12 209-218.

Dattena M, Mara L, Bin TA \& Cappai P 2007 Lambing rate using vitrified blastocysts is improved by culture with BSA and hyaluronan. Molecular Reproduction and Development 74 42-47. (doi:10.1002/mrd.20576)

Day AE, Quilter CR, Sargent CA \& Mileham AJ 2002 Characterization of the porcine sperm adhesion molecule gene SPAM1-expression analysis, genomic structure, and chromosomal mapping. Animal Genetics 33 211-214. (doi:10.1046/j.1365-2052.2002.00830.x)

Deng X, He Y \& Martin-Deleon PA 2000 Mouse Spam1 (PH-20): evidence for its expression in the epididymis and for a new category of spermatogenic-expressed genes. Journal of Andrology 21 822-832.

Dietterich C, Check JH, Summers-Chase D, Yuan W \& Brasile D 2007 'Embryo glue' does not seem to improve chances of subsequent pregnancy in refractory in vitro fertilization cases. Fertility and Sterility 87 S13-S14. (doi:10.1016/j.fertnstert.2007.01.176)

Downing SJ \& Sherwood OD 1986 The physiological role of relaxin in the pregnant rat. IV. The influence of relaxin on cervical collagen and 
glycosaminoglycans. Endocrinology 118 471-479. (doi:10.1210/endo118-2-471)

Downs SM, Daniel SA, Bornslaeger EA, Hoppe PC \& Eppig JJ 1989 Maintenance of meiotic arrest in mouse oocytes by purines: modulation of cAMP levels and cAMP phosphodiesterase activity. Gamete Research 23 323-334. (doi:10.1002/mrd.1120230309)

Dunlap KA, Palmarini M, Adelson DL \& Spencer TE 2005 Sheep endogenous betaretroviruses (enJSRVs) and the hyaluronidase 2 (HYAL2) receptor in the ovine uterus and conceptus. Biology of Reproduction 73 271-279. (doi:10.1095/biolreprod.105.039776)

El-Hayek S \& Clarke HJ 2016 Control of oocyte growth and development by intercellular communication within the follicular niche. Results and Problems in Cell Differentiation 58 191-224. (doi:10.1007/978-3-31931973-5_8)

El Maradny E, Kanayama N, Kobayashi H, Hossain B, Khatun S, Liping S, Kobayashi T \& Terao T 1997 The role of hyaluronic acid as a mediator and regulator of cervical ripening. Human Reproduction 12 1080-1088. (doi:10.1093/humrep/12.5.1080)

Evans EA, Zhang H \& Martin-DeLeon PA 2003 SPAM1 (PH-20) protein and mRNA expression in the epididymides of humans and macaques: utilizing laser microdissection/RT-PCR. Reproductive Biology and Endocrinology 1 54. (doi:10.1186/1477-7827-1-54)

Fernandez S \& Cordoba M 2014 Hyaluronic acid as capacitation inductor: metabolic changes and membrane-associated adenylate cyclase regulation. Reproduction in Domestic Animals 49 941-946. (doi:10.1111/rda.12410)

Feusi E, Sun L, Sibalic A, Beck-Schimmer B, Oertli B \& Wuthrich RP 1999 Enhanced hyaluronan synthesis in the MRL-Fas(lpr) kidney: role of cytokines. Nephron 83 66-73. (doi:10.1159/000045475)

Fancsovits P, Lehner A, Murber A, Kaszas Z, Rigo J \& Urbancsek J 2015 Effect of hyaluronan-enriched embryo transfer medium on IVF outcome: a prospective randomized clinical trial. Archives of Gynecology and Obstetrics 291 1173-1179. (doi:10.1007/s00404-014-3541-9)

Fraser JR, Laurent TC \& Laurent UB 1997 Hyaluronan: its nature, distribution, functions and turnover. Journal of Internal Medicine $\mathbf{2 4 2}$ 27-33. (doi:10.1046/j.1365-2796.1997.00170.x)

Frost GI, Csoka AB, Wong T \& Stern R 1997 Purification, cloning, and expression of human plasma hyaluronidase. Biochemical and Biophysical Research Communications 236 10-15. (doi:10.1006/bbrc.1997.6773)

Fulop C, Szanto S, Mukhopadhyay D, Bardos T, Kamath RV, Rugg MS, Day AJ, Salustri A, Hascall VC, Glant TT et al. 2003 Impaired cumulus mucification and female sterility in tumor necrosis factor-induced protein-6 deficient mice. Development 130 2253-2261. (doi:10.1242/dev.00422)

Furnus CC, de Matos DG \& Martinez AG 1998 Effect of hyaluronic acid on development of in vitro produced bovine embryos. Theriogenology 49 1489-1499. (doi:10.1016/S0093-691X(98)00095-8)

Furnus CC, Valcarcel A, Dulout FN \& Errecalde AL 2003 The hyaluronic acid receptor (CD44) is expressed in bovine oocytes and early stage embryos. Theriogenology 60 1633-1644. (doi:10.1016/S0093-691X(03)00116-X)

Gardner DK, Rodriegez-Martinez H \& Lane M 1999 Fetal development after transfer is increased by replacing protein with the glycosaminoglycan hyaluronan for mouse embryo culture and transfer. Human Reproduction 14 2575-2580. (doi:10.1093/humrep/14.10.2575)

Ghosh I \& Datta K 2003 Sperm surface hyaluronan binding protein (HABP1) interacts with zona pellucida of water buffalo (Bubalus bubalis) through its clustered mannose residues. Molecular Reproduction and Development 64 235-244. (doi:10.1002/mrd.10207)

Ghosh I, Bharadwaj A \& Datta K 2002 Reduction in the level of hyaluronan binding protein 1 (HABP1) is associated with loss of sperm motility. Journal of Reproductive Immunology 53 45-54. (doi:10.1016/S01650378(01)00095-X)

Ghosh I, Chattopadhaya R, Kumar V, Chakravarty BN \& Datta K 2007 Hyaluronan binding protein-1: a modulator of sperm-oocyte interaction. Society of Reproduction and Fertility Supplement 63 539-543.

Girish KS \& Kemparaju K 2007 The magic glue hyaluronan and its eraser hyaluronidase: a biological overview. Life Sciences 80 1921-1943. (doi:10.1016/j.lfs.2007.02.037)

Gmachl M \& Kreil G 1993 Bee venom hyaluronidase is homologous to a membrane protein of mammalian sperm. PNAS 90 3569-3573. (doi:10.1073/pnas.90.8.3569)

Goshen R, Ariel I, Shuster S, Hochberg A, Vlodavsky I, de Groot N, BenRafael Z \& Stern R 1996 Hyaluronan, CD44 and its variant exons in human trophoblast invasion and placental angiogenesis. Molecular Human Reproduction 2 685-691. (doi:10.1093/molehr/2.9.685)

Griffiths GS, Miller KA, Galileo DS \& Martin-DeLeon PA 2008 Murine SPAM1 is secreted by the estrous uterus and oviduct in a form that can bind to sperm during capacitation: acquisition enhances hyaluronic acid-binding ability and cumulus dispersal efficiency. Reproduction 135 293-301. (doi:10.1530/REP-07-0340)

Gutnisky C, Dalvit GC, Pintos LN, Thompson JG, Beconi MT \& Cetica PD 2007 Influence of hyaluronic acid synthesis and cumulus mucification on bovine oocyte in vitro maturation, fertilisation and embryo development. Reproduction, Fertility and Development 19 488-497. (doi:10.1071/RD06134)

Hambiliki F, Ljunger E, Karlström P-O \& Stavreus-Evers A 2010 Hyaluronan-enriched transfer medium in cleavage-stage frozen-thawed embryo transfers increases implantation rate without improvement of delivery rate. Fertility and Sterility 94 1669-1673. (doi:10.1016/j. fertnstert.2009.10.019)

Harada H \& Takahashi M 2007 CD44-dependent intracellular and extracellular catabolism of hyaluronic acid by hyaluronidase- 1 and -2. Journal of Biological Chemistry 282 5597-5607. (doi:10.1074/jbc. M608358200)

Harkness ML \& Harkness RD 1959 Changes in the physical properties of the uterine cervix of the rat during pregnancy. Journal of Physiology $\mathbf{1 4 8}$ 524-547. (doi:10.1113/jphysiol.1959.sp006304)

Hazlett WD, Meyer LR, Nasta TE, Mangan PA \& Karande VC 2008 Impact of EmbryoGlue as the embryo transfer medium. Fertility and Sterility $\mathbf{9 0}$ 214-216. (doi:10.1016/j.fertnstert.2007.05.063)

Hess KA, Chen L \& Larsen WJ 1999 Inter-alpha-Inhibitor binding to Hyaluronan in the cumulus extracellular matrix is required for optimal ovulation and development of mouse oocytes. Biology of Reproduction 61 436-443. (doi:10.1095/biolreprod61.2.436)

Hofinger ES, Hoechstetter J, Oettl M, Bernhardt G \& Buschauer A 2008 Isoenzyme-specific differences in the degradation of hyaluronic acid by mammalian-type hyaluronidases. Glycoconjugate Journal 25 101-109. (doi:10.1007/s10719-007-9058-8)

Homandberg GA, Ummadi V \& Kang H 2004 The role of insulin-like growth factor-I in hyaluronan mediated repair of cultured cartilage explants. Inflammation Research 53 396-404. (doi:10.1007/s00011-004-1276-y)

Huszar G, Ozenci CC, Cayli S, Zavaczki Z, Hansch E \& Vigue L 2003 Hyaluronic acid binding by human sperm indicates cellular maturity, viability, and unreacted acrosomal status. Fertility and Sterility $\mathbf{7 9}$ (Supplement 3) 1616-1624. (doi:10.1016/S0015-0282(03)00402-3)

Illera MJ, Bermejo P, Hernandez J, Gonzalez A \& Illera JC 2004137 The effect of ant-CD44 on embryo implanttaion in rabbits. Reproduction, Fertility and Development 16 190. (doi:10.1071/RDv16n1Ab137)

Irving-Rodgers HF, Mussard ML, Kinder JE \& Rodgers RJ 2002 Composition and morphology of the follicular basal lamina during atresia of bovine antral follicles. Reproduction 123 97-106. (doi:10.1530/rep.0.1230097)

Irving-Rodgers HF \& Rodgers RJ 2005 Extracellular matrix in ovarian follicular development and disease. Cell and Tissue Research 322 89-98. (doi:10.1007/s00441-005-0042-y)

Itano N, Sawai T, Yoshida M, Lenas P, Yamada Y, Imagawa M, Shinomura T, Hamaguchi M, Yoshida Y, Ohnuki Y et al. 1999 Three isoforms of mammalian hyaluronan synthases have distinct enzymatic properties. Journal of Biological Chemistry 274 25085-25092. (doi:10.1074/ jbc.274.35.25085)

Jang G, Lee BC, Kang SK \& Hwang WS 2003 Effect of glycosaminoglycans on the preimplantation development of embryos derived from in vitro fertilization and somatic cell nuclear transfer. Reproduction, Fertility and Development 15 179-185. (doi:10.1071/RD02054)

Kaabi M, Alvarez M, Anel E, Chamorro CA, Boixo JC, de Paz P \& Anel L 2006 Influence of breed and age on morphometry and depth of inseminating catheter penetration in the ewe cervix: a postmortem study. Theriogenology 66 1876-1883. (doi:10.1016/j.theriogenology.2006.04.039)

Kaneiwa T, Miyazaki A, Kogawa R, Mizumoto S, Sugahara K \& Yamada S 2012 Identification of amino acid residues required for the substrate specificity of human and mouse chondroitin sulfate hydrolase (conventional hyaluronidase-4). Journal of Biological Chemistry 287 42119-42128. (doi:10.1074/jbc.M112.360693)

Kang W, Zhou C, Koga Y \& Baba T 2010 Hyaluronan-degrading activity of mouse sperm hyaluronidase is not required for fertilization? Journal of Reproduction and Development 56 140-144. (doi:10.1262/jrd.09-152N) 
Kano K, Miyano T \& Kato S 1998 Effects of glycosaminoglycans on the development of in vitro-matured and -fertilized porcine oocytes to the blastocyst stage in vitro. Biology of Reproduction 58 1226-1232. (doi:10.1095/biolreprod58.5.1226)

Kawakami E, Nishizono Y, Miyata C, Hirano T, Hori T \& Tsutsui T 2006 Effects of hyaluronic acid on $\mathrm{Ca}(2+)$ influx, lactate dehydrogenase activity, and cyclic AMP synthesis in canine ejaculated sperm during In Vitro capacitation. Journal of Veterinary Medical Science 68 119-123. (doi:10.1292/jvms.68.119)

Kennel SJ, Lankford TK, Foote LJ, Shinpock SG \& Stringer C 1993 CD44 expression on murine tissues. Journal of Cell Science 104 373-382.

Kershaw-Young CM, Evans G \& Maxwell WMC 2012 Glycosaminoglycans in the accessory sex glands, testes and seminal plasma of alpaca and ram. Reproduction, Fertility and Development 24 362-369. (doi:10.1071/ RD11152)

Kim E, Baba D, Kimura M, Yamashita M, Kashiwabara S \& Baba T 2005 Identification of a hyaluronidase, Hyal5, involved in penetration of mouse sperm through cumulus mass. PNAS 102 18028-18033. (doi:10.1073/pnas.0506825102)

Kimura N, Konno Y, Miyoshi K, Matsumoto H \& Sato E 2002 Expression of hyaluronan synthases and CD44 messenger RNAs in porcine cumulusoocyte complexes during in vitro maturation. Biology of Reproduction 66 707-717. (doi:10.1095/biolreprod66.3.707)

Kimura N, Hoshino Y, Totsukawa K \& Sato E 2007 Cellular and molecular events during oocyte maturation in mammals: molecules of cumulusoocyte complex matrix and signalling pathways regulating meiotic progression. Society of Reproduction and Fertility Supplement 63 327-342.

Kimura M, Kim E, Kang W, Yamashita M, Saigo M, Yamazaki T, Nakanishi T, Kashiwabara S \& Baba T 2009 Functional roles of mouse sperm hyaluronidases, HYAL5 and SPAM1, in fertilization. Biology of Reproduction 81 939-947. (doi:10.1095/biolreprod.109.078816)

Kobayashi H, Sun GW, Tanaka Y, Kondo T \& Terao T 1999 Serum hyaluronic acid levels during pregnancy and labor. Obstetrics and Gynecology 93 480-484. (doi:10.1016/s0029-7844(98)00526-2)

Kothapalli D, Flowers J, Xu T, Pure E \& Assoian RK 2008 Differential activation of ERK and Rac mediates the proliferative and anti-proliferative effects of hyaluronan and CD44. Journal of Biological Chemistry 283 31823-31829. (doi:10.1074/jbc.M802934200)

Kultti A, Pasonen-Seppanen S, Jauhiainen M, Rilla KJ, Karna R, Pyoria E, Tammi RH \& Tammi MI 2009 4-Methylumbelliferone inhibits hyaluronan synthesis by depletion of cellular UDP-glucuronic acid and downregulation of hyaluronan synthase 2 and 3. Experimental Cell Research 315 1914-1923. (doi:10.1016/j.yexcr.2009.03.002)

Kultti A, Karna R, Rilla K, Nurminen P, Koli E, Makkonen KM, Si J, Tammi MI \& Tammi RH 2010 Methyl-beta-cyclodextrin suppresses hyaluronan synthesis by down-regulation of hyaluronan synthase 2 through inhibition of Akt. Journal of Biological Chemistry 285 22901-22910. (doi:10.1074/jbc.M109.088435)

Lane M, Maybach JM, Hooper K, Hasler JF \& Gardner DK 2003 Cryosurvival and development of bovine blastocysts are enhanced by culture with recombinant albumin and hyaluronan. Molecular Reproduction and Development 64 70-78. (doi:10.1002/mrd.10210)

Lee J \& Spicer A 2000 Hyaluronan: a multifunctional, megaDalton, stealth molecule. Current Opinion in Cell Biology 12 581-586. (doi:10.1016/ S0955-0674(00)00135-6)

Lepperdinger G, Mullegger J \& Kreil G 2001 Hyal2 - less active, but more versatile? Matrix Biology 20 509-514. (doi:10.1016/S0945053X(01)00170-6)

Leppert PC 1992 Cervical softening, effacement, and dilatation. Journal of Maternal-Fetal and Neonatal Medicine 1 213-223. (doi:10.3109/14767059209161921)

Li H, Moll J, Winkler A, Frappart L, Brunet S, Hamann J, Kroll T, Verlhac MH, Heuer H, Herrlich P et al. 2015 RHAMM deficiency disrupts folliculogenesis resulting in female hypofertility. Biology Open 4 562-571. (doi:10.1242/bio.201410892)

López J, Valdez-Morales FJ, Benítez-Bribiesca L, Cerbón M \& Carrancá AG 2013 Normal and cancer stem cells of the human female reproductive system. Reproductive Biology and Endocrinology 1153. (doi:10.1186/1477-7827-11-53)

Loutradi KE, Prassas I, Bili E, Sanopoulou T, Bontis I \& Tarlatzis BC 2007 Evaluation of a transfer medium containing high concentration of hyaluronan in human in vitro fertilization. Fertility and Sterility $\mathbf{8 7}$ 48-52. (doi:10.1016/j.fertnstert.2006.05.060)

Loutradi KE, Tarlatzi TB, Kolibianakis EM \& Tarlatzis BC 2008 Does hyaluronan improve embryo implantation? Current Opinion in Obstetrics and Gynecology 20 305-307. (doi:10.1097/GCO.0b013e3282f8b01a)

Macaulay AD, Gilbert I, Scantland S, Fournier E, Ashkar F, Bastien A, Saadi HA, Gagne D, Sirard MA, Khandjian EW et al. 2016 Cumulus cell transcripts transit to the bovine oocyte in preparation for maturation. Biology of Reproduction 94 16. (doi:10.1095/biolreprod.114.127571)

Maioral GC, Gomes RC, Verna C, Simões MJ, Nader HB, Simões RS, Baracat EC \& Soares-Jr JM 2016 Concentration of glycosaminoglycan in ovariectomized mice uterus after treatment with ovarian steroids. Gynecological Endocrinology 21 1-5. (doi:10.3109/09513590.2016.1 147027)

Magier S, van der Ven HH, Diedrich K \& Krebs D 1990 Significance of cumulus oophorus in in-vitro fertilization and oocyte viability and fertility. Human Reproduction 5 847-852.

Manicourt DH, Triki R, Fukuda K, Devogelaer JP, Nagant de Deuxchaisnes C \& Thonar EJ 1993 Levels of circulating tumor necrosis factor alpha and interleukin- 6 in patients with rheumatoid arthritis. Relationship to serum levels of hyaluronan and antigenic keratan sulfate. Arthritis and Rheumatology 36 490-499. (doi:10.1002/art.1780360409)

Marei WF, Ghafari F \& Fouladi-Nashta AA 2012 Role of hyaluronic acid in maturation and further early embryo development of bovine oocytes. Theriogenology 78 670-677. (doi:10.1016/j. theriogenology.2012.03.013)

Marei WF, Salavati M \& Fouladi-Nashta AA 2013 Critical role of hyaluronidase-2 during preimplantation embryo development. Molecular Human Reproduction 19 590-599. (doi:10.1093/molehr/ gat032)

Marei WF, Raheem KA, Salavati M, Tremaine T, Khalid M \& FouladiNashta AA 2016a Hyaluronan and hyaluronidase, which is better for embryo development? Theriogenology 86 940-948. (doi:10.1016/j. theriogenology.2016.03.017)

Marei WF, Wathes DC, Raheem KA, Mohey-Elsaeed O, Ghafari F \& Fouladi-Nashta AA $2016 b$ Influence of hyaluronan on endometrial receptivity and embryo attachment in sheep. Reproduction, Fertility and Development. (doi:10.1071/RD16232)

Marek DE, Langley MT, Weiand LA, Nackley AC, Doody KM \& Doody KJ 2004 Comparison of embryo transfers performed with G2.3 and embryo glue. Fertility and Sterility 82 (Supplement 2) S26-S27. (doi:10.1016/j. fertnstert.2004.07.073)

Martin-DeLeon PA 2006 Epididymal SPAM1 and its impact on sperm function. Molecular and Cellular Endocrinology 250 114-121. (doi:10.1016/j.mce.2005.12.033)

Martins JR, Passerotti CC, Maciel RM, Sampaio LO, Dietrich CP \& Nader HB 2003 Practical determination of hyaluronan by a new noncompetitive fluorescence-based assay on serum of normal and cirrhotic patients. Analytical Biochemistry 319 65-72. (doi:10.1016/ S0003-2697(03)00251-3)

Matou-Nasri S, Gaffney J, Kumar S \& Slevin A 2009 Oligosaccharides of hyaluronan induce angiogenesis through distinct CD44 and RHAMM-mediated signalling pathways involving Cdc2 and $\gamma$ adducin. International Journal of Oncology 35 761-773. (doi:10.3892/ ijo_00000389)

Matsumoto H, Daikoku T, Wang H, Sato E \& Dey SK 2004 Differential expression of ezrin/radixin/moesin (ERM) and ERM-associated adhesion molecules in the blastocyst and uterus suggests their functions during implantation. Biology of Reproduction 70 729-736. (doi:10.1095/ biolreprod.103.022764)

Misra S, Hascall VC, Markwald RR \& Ghatak S 2015 Interactions between hyaluronan and its receptors (CD44, RHAMM) regulate the activities of inflammation and cancer. Frontiers in Immunology 6 201. (doi:10.3389/ fimmu.2015.00201)

Miyake Y, Matsumoto H, Yokoo M, Miyazawa K, Kimura N, Tunjung WAS, Shimizu T, Sasada H, Aso H, Yamaguchi T et al. 2006 Expression and glycosylation with polylactosamine of CD44 antigen on macrophages during follicular atresia in pig ovaries. Biology of Reproduction 74 501-510. (doi:10.1095/biolreprod.105.045641)

Miyake Y, Sakurai M, Tanaka S, Tunjung WAS, Yokoo M, Matsumoto H, Aso H, Yamaguchi T \& Sato E 2009 Expression of hyaluronan synthase 1 and distribution of hyaluronan during follicular atresia 
in pig ovaries. Biology of Reproduction 80 249-257. (doi:10.1095/ biolreprod.108.067694)

Modelski MJ, Menlah G, Wang Y, Dash S, Wu K, Galileo DS \& MartinDeLeon PA 2014 Hyaluronidase 2: a novel germ cell hyaluronidase with epididymal expression and functional roles in mammalian sperm. Biology of Reproduction 91 109. (doi:10.1095/biolreprod.113.115857)

Mohapatra S, Yang X, Wright JA, Turley EA \& Greenberg AH 1996 Soluble hyaluronan receptor RHAMM induces mitotic arrest by suppressing Cdc2 and cyclin B1 expression. Journal of Experimental Medicine 183 1663-1668. (doi:10.1084/jem.183.4.1663)

Mohey-Elsaeed O, Marei WF, Fouladi-Nashta AA \& El-Saba AA 2015 Histochemical structure and immunolocalisation of the hyaluronan system in the dromedary oviduct. Reproduction, Fertility and Development 28 936-947. (doi:10.1071/RD14187)

Montjean D, Belloc S, Benkhalifa M, Dalleac A \& Ménézo Y 2012 Sperm vacuoles are linked to capacitation and acrosomal status. Human Reproduction 27 2927-2932. (doi:10.1093/humrep/des266)

Morin G, Sullivan R, Laflamme I, Robert C \& Leclerc P 2010 SPAM1 isoforms from two tissue origins are differentially localized within ejaculated bull sperm membranes and have different roles during fertilization. Biology of Reproduction 82 271-281. (doi:10.1095/ biolreprod.109.079582)

Myles DG \& Primakoff P 1997 Why did the sperm cross the cumulus? To get to the oocyte. Functions of the sperm surface proteins $\mathrm{PH}-20$ and fertilin in arriving at, and fusing with, the egg. Biology of Reproduction 56 320-327. (doi:10.1095/biolreprod56.2.320)

Nagyova E 2015 Regulation of cumulus expansion and hyaluronan synthesis in porcine oocyte-cumulus complexes during in vitro maturation. Endocrine Regulations 46 225-235. (doi:10.4149/endo_2012_04_225)

Nagyova E, Camaioni A, Prochazka R \& Salustri A 2004 Covalent transfer of heavy chains of inter-alpha-trypsin inhibitor family proteins to hyaluronan in in vivo and in vitro expanded porcine oocyte-cumulus complexes. Biology of Reproduction 71 1838-1843. (doi:10.1095/ biolreprod.104.029595)

Nakagawa K, Takahashi C, Nishi Y, Jyuen H, Sugiyama R \& Kuribayashi Y 2012 Hyaluronan-enriched transfer medium improves outcome in patients with multiple embryo transfer failures. Journal of Assisted Reproduction and Genetics 29 679-685. (doi:10.1007/s10815-0129758-2)

Nakamura T, Funahashi M, Takagaki K, Munakata H, Tanaka K, Saito Y \& Endo M 1997 Effect of 4-methylumbelliferone on cell-free synthesis of hyaluronic acid. Biochemistry and Molecular Biology International 43 263-268. (doi:10.1080/15216549700204041)

Necas J, Bartosikova L, Brauner P \& Kolar J 2008 Hyaluronic acid (hyaluronan): a review. Veterinarni Medicina 53 397-411.

Nieuwdorp M, Holleman F, de Groot E, Vink H, Gort J, Kontush A, Chapman MJ, Hutten BA, Brouwer CB, Hoekstra JB et al. 2007 Perturbation of hyaluronan metabolism predisposes patients with type 1 diabetes mellitus to atherosclerosis. Diabetologia 50 1288-1293. (doi:10.1007/s00125-007-0666-4)

Noble PW 2002 Hyaluronan and its catabolic products in tissue injury and repair. Matrix Biology 21 25-29. (doi:10.1016/S0945-053X(01)00184-6)

Norris RP, Ratzan WJ, Freudzon M, Mehlmann LM, Krall J, Movsesian MA, Wang H, Ke H, Nikolaev VO et al. 2009 Cyclic GMP from the surrounding somatic cells regulates cyclic AMP and meiosis in the mouse oocyte. Development 136 1869-1878. (doi:10.1242/dev.035238)

Nykopp TK, Rilla K, Sironen R, Tammi MI, Tammi RH, Hamalainen K, Heikkinen AM, Komulainen M, Kosma VM \& Anttila M 2009 Expression of hyaluronan synthases (HAS1-3) and hyaluronidases (HYAL1-2) in serous ovarian carcinomas: inverse correlation between HYAL1 and hyaluronan content. BMC Cancer 9 143. (doi:10.1186/1471-2407-9-143)

Nykopp TK, Rilla K, Tammi MI, Tammi RH, Sironen R, Hamalainen K, Kosma VM, Heinonen S \& Anttila M 2010 Hyaluronan synthases (HAS1-3) and hyaluronidases (HYAL1-2) in the accumulation of hyaluronan in endometrioid endometrial carcinoma. BMC Cancer 10 512. (doi:10.1186/1471-2407-10-512)

Oguchi T \& Ishiguro N 2004 Differential stimulation of three forms of hyaluronan synthase by TGF-beta, IL-1 beta, and TNF-alpha. Connective Tissue Research 45 197-205. (doi:10.1080/03008200490523031)

Ohta N, Saito H, Kaneko T, Yoshida M, Takahashi T, Saito T, Nakahara K \& Hiroi M 2001 Soluble CD44 in human ovarian follicular fluid. Journal of Assisted Reproduction and Genetics 18 21-25. (doi:10.102 3/A:1026494528415)
Opiela J, Romanek J, Lipinski D \& Smorag Z 2014 Effect of hyaluronan on developmental competence and quality of oocytes and obtained blastocysts from in vitro maturation of bovine oocytes. BioMed Research International 2014 519189. (doi:10.1155/2014/519189)

Overstreet JW, Lin Y, Yudin AI, Meyers SA, Primakoff P, Myles DG, Katz DF \& Vandevoort CA 1995 Location of the $\mathrm{PH}-20$ protein on acrosomeintact and acrosome-reacted spermatozoa of cynomolgus macaques. Biology of Reproduction 52 105-114. (doi:10.1095/biolreprod52.1.105)

Ozbilgin K, Boz B, Tugyan K, Inan S \& Vatansever S 2012 RHAMM expression in the rat endometrium during the estrous cycle and following implantation. Journal of Reproduction and Infertility 13 131-137.

Palasz A, Alkemade S \& Mapletoft RJ 1993 The use of sodium hyaluronate in freezing media for bovine and murine embryos. Cryobiology $\mathbf{3 0}$ 172-178. (doi:10.1006/cryo.1993.1016)

Palasz AT, Rodriguez-Martinez H, Beltran-Brena P, Perez-Garnelo S, Martinez MF, Gutierrez-Adan A \& De la Fuente J 2006 Effects of hyaluronan, BSA, and serum on bovine embryo in vitro development, ultrastructure, and gene expression patterns. Molecular Reproduction and Development 73 1503-1511. (doi:10.1002/mrd.20516)

Pasonen-Seppanen S, Karvinen S, Torronen K, Hyttinen JM, Jokela T, Lammi MJ, Tammi MI \& Tammi R 2003 EGF upregulates, whereas TGF-beta downregulates, the hyaluronan synthases Has2 and Has3 in organotypic keratinocyte cultures: correlations with epidermal proliferation and differentiation. Journal of Investigative Dermatology 120 1038-1044. (doi:10.1046/j.1523-1747.2003.12249.x)

Pena FJ, Johannisson A, Wallgren M \& Rodriguez-Martinez H 2004 Effect of hyaluronan supplementation on boar sperm motility and membrane lipid architecture status after cryopreservation. Theriogenology $\mathbf{6 1}$ 63-70. (doi:10.1016/S0093-691X(03)00181-X)

Perry K, Haresign W, Wathes DC \& Khalid M 2010a Hyaluronan (HA) content, the ratio of HA fragments and the expression of CD44 in the ovine cervix vary with the stage of the oestrous cycle. Reproduction 140 133-141. (doi:10.1530/REP-09-0424)

Perry K, Haresign W, Wathes DC \& Khalid M 2010 b Intracervical application of hyaluronan improves cervical relaxation in the ewe. Theriogenology 74 1685-1690. (doi:10.1016/j.theriogenology.2010.07.008)

Perry K, Haresign W, Wathes DC, Pitsillides AA \& Khalid M 2012 Cervical expression of hyaluronan synthases varies with the stage of the estrous cycle in the ewe. Theriogenology 77 1100-1110. (doi:10.1016/j. theriogenology.2011.10.012)

Pienimaki JP, Rilla K, Fulop C, Sironen RK, Karvinen S, Pasonen S, Lammi MJ, Tammi R, Hascall VC \& Tammi MI 2001 Epidermal growth factor activates hyaluronan synthase 2 in epidermal keratinocytes and increases pericellular and intracellular hyaluronan. Journal of Biological Chemistry 276 20428-20435. (doi:10.1074/jbc.M007601200)

Pregl Breznik B, Kovacic B \& Vlaisavljevic V 2013 Are sperm DNA fragmentation, hyperactivation, and hyaluronan-binding ability predictive for fertilization and embryo development in in vitro fertilization and intracytoplasmic sperm injection? Fertility and Sterility 99 1233-1241. (doi:10.1016/j.fertnstert.2012.11.048)

Prehm P 1984 Hyaluronate is synthesized at plasma membranes. Biochemical Journal 220 597-600. (doi:10.1042/bj2200597)

Prinosilova P, Zajicova A \& Veznik Z 2009 Effect of hyaluronan supplementation on dog sperm motility and membrane integrity after cryopreservation. Reproduction in Domestic Animals 44 121-121. (doi:10.1111/j.1439-0531.2009.01488_3.x)

Pure E \& Assoian RK 2009 Rheostatic signaling by CD44 and hyaluronan. Cellular Signalling 21 651-655. (doi:10.1016/j.cellsig.2009.01.024)

Qian L, Yu S \& Zhou Y 2016 Protective effect of hyaluronic acid on cryopreserved boar sperm. International Journal of Biological Macromolecules 87 287-289. (doi:10.1016/j.ijbiomac.2016.02.075)

Raheem KA, Marei WF, Mifsud K, Khalid M, Wathes DC \& FouladiNashta AA 2013 Regulation of the hyaluronan system in ovine endometrium by ovarian steroids. Reproduction 145 491-504. (doi:10.1530/REP-13-0001)

Rajabi MR, Quillen EW Jr, Nuwayhid BS, Brandt R \& Poole AR 1992 Circulating hyaluronic acid in nonpregnant, pregnant, and postpartum guinea pigs: elevated levels observed at parturition. American Journal of Obstetrics and Gynecology 166 242-246. (doi:10.1016/00029378(92)91866-9)

Ranganathan S, Ganguly AK \& Datta K 1994 Evidence for presence of hyaluronan binding protein on spermatozoa and its possible involvement 
in sperm function. Molecular Reproduction and Development 38 69-76. (doi:10.1002/mrd.1080380112)

Ranganathan S, Bharadwaj A \& Datta K 1995 Hyaluronan mediates sperm motility by enhancing phosphorylation of proteins including hyaluronan binding protein. Cellular and Molecular Biology Research 41 467-476.

Rashki Ghaleno L, Rezazadeh Valojerdi M, Chehrazi M, Sahraneshin Samani F \& Salman Yazdi R 2016 Hyaluronic acid binding assay is highly sensitive to select human spermatozoa with good progressive motility, morphology, and nuclear maturity. Gynecologic and Obstetric Investigation 81 244-250. (doi:10.1159/000439530)

Rayahin JE, Buhrman JS, Zhang Y, Koh TJ \& Gemeinhart RA 2015 High and low molecular weight hyaluronic acid differentially influence macrophage activation. ACS Biomaterials Science and Engineering 1 481-493. (doi:10.1021/acsbiomaterials.5b00181)

Reddy JM, Joyce C \& Zaneveld LJD 1980 Role of hyaluronidase in fertilization - the anti-fertility activity of myocrisin, a nontoxic hyaluronidase inhibitor. Journal of Andrology 1 28-32. (doi:10.1002/j.1939-4640.1980.tb00006.x)

Reitinger S, Laschober GT, Fehrer C, Greiderer B \& Lepperdinger G 2007 Mouse testicular hyaluronidase-like proteins SPAM1 and HYAL5 but not HYALP1 degrade hyaluronan. Biochemical Journal 401 79-85. (doi:10.1042/BJ20060598)

Richards JS, Russell DL, Ochsner S \& Espey LL 2002 Ovulation: new dimensions and new regulators of the inflammatory-like response. Biology of Reproduction 64 69-92. (doi:10.1146/annurev. physiol.64.081501.131029)

Rodgers RJ \& Irving-Rodgers HF 2010 Formation of the ovarian follicular antrum and follicular fluid. Biology of Reproduction 82 1021-1029. (doi:10.1095/biolreprod.109.082941)

Rodgers RJ, Irving-Rodgers HF \& Russell DL 2003 Extracellular matrix of the developing ovarian follicle. Reproduction 126 415-424. (doi:10.1530/ rep.0.1260415)

Rodriguez HI, Stewart AJ, Wolfe DF, Caldwell FJ, Harrie M \& Whitley EM 2011 Immunolocalization of the hyaluronan receptor CD44 in the reproductive tract of the mare. Theriogenology 75 276-286. (doi:10.1016/j.theriogenology.2010.08.014)

Russell DL, Gilchrist RB, Brown HM \& Thompson JG 2016 Bidirectional communication between cumulus cells and the oocyte: old hands and new players? Theriogenology 86 62-68. (doi:10.1016/j. theriogenology.2016.04.019)

Sabeur K, Cherr GN, Yudin AI \& Overstreet JW 1998 Hyaluronic acid enhances induction of the acrosome reaction of human sperm through interaction with the PH-20 protein. Zygote 6 103-111. (doi:10.1017/ S0967199498000021)

Saito H, Kaneko T, Takahashi T, Kawachiya S, Saito T \& Hiroi M 2000 Hyaluronan in follicular fluids and fertilization of oocytes. Fertility and Sterility 74 1148-1152. (doi:10.1016/S0015-0282(00)01586-7)

Sakairi A, Tsukise A \& Meyer W 2007 Localization of hyaluronic acid in the seminal vesicles of the miniature pig. Anatomia, Histologia, Embryologia 36 4-9. (doi:10.1111/j.1439-0264.2006.00700.x)

Salustri A, Yanagishita M \& Hascall VC 1989 Synthesis and accumulation of hyaluronic acid and proteoglycans in the mouse cumulus cell-oocyte complex during follicle-stimulating hormone-induced mucification. Journal of Biological Chemistry 264 13840-13847.

Salustri A, Yanagishita M, Underhill CB, Laurent TC \& Hascall VC 1992 Localization and synthesis of hyaluronic acid in the cumulus cells and mural granulosa cells of the preovulatory follicle. Developmental Biology 151 541-551. (doi:10.1016/0012-1606(92)90192-J)

Salustri A, Camaioni A, Di Giacomo M, Fulop C \& Hascall VC 1999 Hyaluronan and proteoglycans in ovarian follicles. Human Reproduction Update 5 293. (doi:10.1093/humupd/5.4.293)

Salustri A, Garlanda C, Hirsch E, De Acetis M, Maccagno A, Bottazzi B, Doni A, Bastone A, Mantovani G, Beck Peccoz P et al. 2004 PTX3 plays a key role in the organization of the cumulus oophorus extracellular matrix and in in vivo fertilization. Development 131 1577-1586. (doi:10.1242/dev.01056)

Sanchez F \& Smitz J 2012 Molecular control of oogenesis. Biochimica et Biophysica Acta 1822 1896-1912. (doi:10.1016/j. bbadis.2012.05.013)

Sato E \& Yokoo M 2005 Morphological and biochemical dynamics of porcine cumulus-oocyte complexes: role of cumulus expansion in oocyte maturation. Italian Journal of Anatomy and Embryology 110 205-217.
Sato H, Kajikawa S, Kuroda S, Horisawa Y, Nakamura N, Kaga N, Kakinuma C, Kato K, Morishita H, Niwa H et al. 2001 Impaired fertility in female mice lacking urinary trypsin inhibitor. Biochemical and Biophysical Research Communications 281 1154-1160. (doi:10.1006/ bbrc.2001.4475)

Saylan A \& Duman S 2016 Efficacy of hyaluronic acid in the selection of human spermatozoa with intact DNA by the swim-up method. Cell Journal 18 83-88.

Schoenfelder M \& Einspanier R 2003 Expression of hyaluronan synthases and corresponding hyaluronan receptors is differentially regulated during oocyte maturation in cattle. Biology of Reproduction 69 269-277. (doi:10.1095/biolreprod.102.011577)

Sela-Abramovich S, Chorev E, Galiani D \& Dekel N 2005 Mitogenactivated protein kinase mediates luteinizing hormone-induced breakdown of communication and oocyte maturation in rat ovarian follicles. Endocrinology 146 1236-1244. (doi:10.1210/en.2004-1006)

Shimada M, Yanai Y, Okazaki T, Noma N, Kawashima I, Mori T \& Richards JS 2008 Hyaluronan fragments generated by sperm-secreted hyaluronidase stimulate cytokine/chemokine production via the TLR2 and TLR4 pathway in cumulus cells of ovulated COCs, which may enhance fertilization. Development 135 2001-2011. (doi:10.1242/ dev.020461)

Simon A 2003 Hyaluronic acid can successfully replace albumin as the sole macromolecule in a human embryo transfer medium. Fertility and Sterility 79 1434-1438. (doi:10.1016/S0015-0282(03)00349-2)

Skarzynski DJ, Piotrowska-Tomala KK, Lukasik K, Galvao A, Farberov S, Zalman Y \& Meidan R 2013 Growth and regression in bovine corpora lutea: regulation by local survival and death pathways. Reproduction in Domestic Animals 48 (Supplement 1) 25-37. (doi:10.1111/rda.12203)

Stern R 2003 Devising a pathway for hyaluronan catabolism: are we there yet? Glycobiology 13 105R-115R. (doi:10.1093/glycob/cwg112)

Stern R 2004 Hyaluronan catabolism: a new metabolic pathway. European Journal of Cell Biology 83 317-325. (doi:10.1078/0171-9335-00392)

Stern R, Asari AA \& Sugahara KN 2006 Hyaluronan fragments: an information-rich system. European Journal of Cell Biology 85 699-715. (doi:10.1016/j.ejcb.2006.05.009)

Stock AE, Bouchard N, Brown K, Spicer AP, Underhill CB, Doré M \& Sirois J 2002 Induction of hyaluronan synthase 2 by human chorionic gonadotropin in mural granulosa cells of equine preovulatory follicles. Endocrinology 143 4375-4384. (doi:10.1210/en.2002-220563)

Stojkovic M, Kolle S, Peinl S, Stojkovic P, Zakhartchenko V, Thompson JG, Wenigerkind H, Reichenbach HD, Sinowatz F \& Wolf E 2002 Effects of high concentrations of hyaluronan in culture medium on development and survival rates of fresh and frozen-thawed bovine embryos produced in vitro. Reproduction 124 141-153. (doi:10.1530/rep.0.1240141)

Stojkovic M, Krebs O, Kölle S, Prelle K, Assmann V, Zakhartchenko V, Sinowatz F \& Wolf E 2003 Developmental regulation of hyaluronanbinding protein (RHAMM/IHABP) expression in early bovine embryos. Biology of Reproduction 68 60-66. (doi:10.1095/biolreprod.102.007716)

Straach KJ, Shelton JM, Richardson JA, Hascall VC \& Mahendroo MS 2005 Regulation of hyaluronan expression during cervical ripening. Glycobiology 15 55-65. (doi:10.1093/glycob/cwh137)

Sussmann M, Sarbia M, Meyer-Kirchrath J, Nusing RM, Schror K \& Fischer JW 2004 Induction of hyaluronic acid synthase 2 (HAS2) in human vascular smooth muscle cells by vasodilatory prostaglandins. Circulation Research 94 592-600. (doi:10.1161/01.RES.0000119169.87429.A0)

Suzuki K, Asano A, Eriksson B, Niwa K, Nagai T \& Rodriguez-Martinez H 2002 Capacitation status and in vitro fertility of boar spermatozoa: effects of seminal plasma, cumulus-oocyte-complexes-conditioned medium and hyaluronan. International Journal of Andrology 25 84-93. (doi:10.1046/j.1365-2605.2002.00330.x)

Takahashi N, Tarumi W \& Ishizuka B 2014 Involvement of hyaluronan synthesis in ovarian follicle growth in rats. Reproduction 147 189-197. (doi:10.1530/REP-13-0464)

Tammi R, Ronkko S, Agren UM \& Tammi M 1994 Distribution of hyaluronan in bull reproductive organs. Journal of Histochemistry and Cytochemistry 42 1479-1486. (doi:10.1177/42.11.7523491)

Tammi MI, Day AJ \& Turley EA 2002 Hyaluronan and homeostasis: a balancing act. Journal of Biological Chemistry 277 4581-4584. (doi:10.1074/jbc.R100037200)

Tammi RH, Passi AG, Rilla K, Karousou E, Vigetti D, Makkonen K \& Tammi MI 2011 Transcriptional and post-translational regulation of 
hyaluronan synthesis. FEBS Journal 278 1419-1428. (doi:10.1111/ j.1742-4658.2011.08070.x)

Tanghe S, Van Soom A, Nauwynck H, Coryn M \& de Kruif A 2002 Minireview: functions of the cumulus oophorus during oocyte maturation, ovulation, and fertilization. Molecular Reproduction and Development 61 414-424. (doi:10.1002/mrd.10102)

Teixeira Gomes RC, Verna C, Nader HB, dos Santos Simoes R, Dreyfuss JL, Martins JR, Baracat EC, de Jesus Simoes M \& Soares JM Jr2009 Concentration and distribution of hyaluronic acid in mouse uterus throughout the estrous cycle. Fertility and Sterility 92 785-792. (doi:10.1016/j.fertnstert.2008.07.005)

Thakur SC, Kumar V, Ghosh I, Bharadwaj A \& Datta K 2006 Appearance of hyaluronan binding protein 1 proprotein in pachytene spermatocytes and round spermatids correlates with spermatogenesis. Journal of Andrology 27 604-610. (doi:10.2164/jandrol.05142)

Thompson CB, Shepard HM, O'Connor PM, Kadhim S, Jiang P, Osgood RJ, Bookbinder LH, Li X, Sugarman BJ, Connor RJ et al. 2010 Enzymatic depletion of tumor hyaluronan induces antitumor responses in preclinical animal models. Molecular Cancer Therapeutics 9 3052-3064. (doi:10.1158/1535-7163.MCT-10-0470)

Tienthai P 2015 The porcine sperm reservoir in relation to the function of hyaluronan. Journal of Reproduction and Development 61 245-250. (doi:10.1262/jrd.2015-006)

Tienthai P, Kjellen L, Pertoft H, Suzuki K \& Rodriguez-Martinez H 2000 Localization and quantitation of hyaluronan and sulfated glycosaminoglycans in the tissues and intraluminal fluid of the pig oviduct. Reproduction, Fertility and Development 12 173-182. (doi:10.1071/RD00034)

Tienthai P, Kimura N, Heldin P, Sato E \& Rodriguez-Martinez H 2003 Expression of hyaluronan synthase-3 in porcine oviducal epithelium during oestrus. Reproduction, Fertility and Development 15 99-105. (doi:10.1071/RD02100)

Tienthai P, Johannisson A \& Rodriguez-Martinez H 2004 Sperm capacitation in the porcine oviduct. Animal Reproduction Science $\mathbf{8 0}$ 131-146. (doi:10.1016/S0378-4320(03)00134-9)

Tirone E, CD'Alessandris, Hascall VC, Siracusa G \& Salustri A 1997 Hyaluronan synthesis by mouse cumulus cells is regulated by interactions between follicle-stimulating hormone (or epidermal growth factor) and a soluble oocyte factor (or transforming growth factor beta1). Journal of Biological Chemistry 272 4787-4794. (doi:10.1074/ jbc.272.8.4787)

Tolg C, Poon R, Fodde R, Turley EA \& Alman BA 2003 Genetic deletion of receptor for hyaluronan-mediated motility (Rhamm) attenuates the formation of aggressive fibromatosis (desmoid tumor). Oncogene 22 6873-6882. (doi:10.1038/sj.onc.1206811)

Toole BP 2004 Hyaluronan: from extracellular glue to pericellular cue. Nature Reviews Cancer 4 528-539. (doi:10.1038/nrc1391)

Toole BP 2009 Hyaluronan-CD44 interactions in cancer: paradoxes and possibilities. Clinical Cancer Research 15 7462-7468. (doi:10.1158/1078-0432.CCR-09-0479)

Toyokawa K, Harayama H \& Miyake M 2005 Exogenous hyaluronic acid enhances porcine parthenogenetic embryo development in vitro possibly mediated by CD44. Theriogenology 64 378-392. (doi:10.1016/j. theriogenology.2004.12.005)

Turley EA, Noble PW \& Bourguignon LY 2002 Signaling properties of hyaluronan receptors. Journal of Biological Chemistry 277 4589-4592. (doi:10.1074/jbc.R100038200)

Turner R, Mendel G, Wauthier E, Barbier C \& Reid LM 2012 Hyaluronansupplemented buffers preserve adhesion mechanisms facilitating cryopreservation of human hepatic stem/progenitor cells. Cell Transplantation 21 2257-2266. (doi:10.3727/096368912X637000)

Uchiyama T, Sakuta T \& Kanayama T 2005 Regulation of hyaluronan synthases in mouse uterine cervix. Biochemical and Biophysical Research Communications 327 927-932. (doi:10.1016/j.bbrc.2004.12.092)

Ueno S, Yoshida N \& Niimura S 2009 Amount of hyaluronan produced by mouse oocytes and role of hyaluronan in enlargement of the perivitelline space. Journal of Reproduction and Development 55 496-501. (doi:10.1262/jrd.20226)

Ulbrich SE, Schoenfelder M, Thoene S \& Einspanier R 2004 Hyaluronan in the bovine oviduct - modulation of synthases and receptors during the estrous cycle. Molecular and Cellular Endocrinology 214 9-18. (doi:10.1016/j.mce.2003.12.002)

Urman B, Yakin K, Ata B, Isiklar A \& Balaban B 2008 Effect of hyaluronanenriched transfer medium on implantation and pregnancy rates after day 3 and day 5 embryo transfers: a prospective randomized study. Fertility and Sterility 90 604-612. (doi:10.1016/j.fertnstert.2007.07.1294)

Weissmann B, Meyer K, Sampson P \& Linker A 1954 Isolation of oligosaccharides enzymatically produced from hyaluronic acid. Journal of Biological Chemistry 208 417-429.

Worrilow KC, Eid S, Woodhouse D, Perloe M, Smith S, Witmyer J, Ivani K, Khoury C, Ball GD, Elliot T et al. 2013 Use of hyaluronan in the selection of sperm for intracytoplasmic sperm injection (ICSI): significant improvement in clinical outcomes - multicenter, double-blinded and randomized controlled trial. Human Reproduction 28 306-314. (doi:10.1093/humrep/des417)

Xu H, Ito T, Tawada A, Maeda H, Yamanokuchi H, Isahara K, Yoshida K, Uchiyama Y \& Asari A 2002 Effect of hyaluronan oligosaccharides on the expression of heat shock protein 72. Journal of Biological Chemistry 277 17308-17314. (doi:10.1074/jbc.M112371200)

Ye H, Huang GN, Gao Y \& Liu de Y 2006 Relationship between human sperm-hyaluronan binding assay and fertilization rate in conventional in vitro fertilization. Human Reproduction 21 1545-1550. (doi:10.1093/ humrep/del008)

Yogev L, Kleiman SE, Hauser R, Botchan A, Lehavi O, Paz G \& Yavetz H 2010 Assessing the predictive value of hyaluronan binding ability for the freezability potential of human sperm. Fertility and Sterility 93 154-158. (doi:10.1016/j.fertnstert.2008.09.067)

Yokoo M, Kimura N \& Sato E 2010 Induction of oocyte maturation by hyaluronan-CD44 interaction in pigs. Journal of Reproduction and Development 56 15-19. (doi:10.1262/jrd.09-173E)

Zhang H \& Martin-DeLeon PA 2001 Mouse epididymal Spam1 (PH-20) is released in vivo and in vitro, and Spam 1 is differentially regulated in testis and epididymis. Biology of Reproduction 65 1586-1593. (doi:10.1095/biolreprod65.5.1586)

Zhang H \& Martin-DeLeon PA 2003 Mouse Spam1 (PH-20) is a multifunctional protein: evidence for its expression in the female reproductive tract. Biology of Reproduction 69 446-454. (doi:10.1095/ biolreprod.102.013854)

Zhang H, Shertok S, Miller K, Taylor L \& Martin-Deleon PA 2005 Sperm dysfunction in the $\mathrm{Rb}(6.16)$ - and $\mathrm{Rb}(6.15)$-bearing mice revisited: involvement of Hyalp1 and Hyal5. Molecular Reproduction and Development 72 404-410. (doi:10.1002/mrd.20360)

Zheng Y, Deng X, Zhao Y, Zhang H \& Martin-DeLeon PA 2001 Spam1 (PH-20) mutations and sperm dysfunction in mice with the Rb(6.16) or $\mathrm{Rb}(6.15)$ translocation. Mammalian Genome 12 822-829. (doi:10.1007/ s00335-001-1008-3)

Zhou C, Kang W \& Baba T 2012 Functional characterization of doubleknockout mouse sperm lacking SPAM1 and ACR or SPAM1 and PRSS21 in fertilization. Journal of Reproduction and Development 58 330-337. (doi:10.1262/jrd.2011-006)

Zhu R, Huang YH, Tao Y, Wang SC, Sun C, Piao HL, Wang XQ, Du MR \& Li DJ 2013a Hyaluronan up-regulates growth and invasion of trophoblasts in an autocrine manner via PI3K/AKT and MAPK/ERK1/2 pathways in early human pregnancy. Placenta 34 784-791. (doi:10.1016/j. placenta.2013.05.009)

Zhu R, Wang SC, Sun C, Tao Y, Piao HL, Wang XQ, Du MR \& Da-Jin L $2013 b$ Hyaluronan-CD44 interaction promotes growth of decidual stromal cells in human first-trimester pregnancy. PLOS ONE 8 e74812. (doi:10.1371/journal.pone.0074812)

Zhuo L \& Kimata K 2001 Cumulus oophorus extracellular matrix: its construction and regulation. Cell Structure and Function 26 189-196. (doi:10.1247/csf.26.189)

Received 3 May 2016

First decision 7 June 2016

Revised manuscript received 14 October 2016

Accepted 26 October 2016 